\title{
The Supreme Court as Interstitial Actor: Justice Ginsburg's Eclectic Approach to Statutory Interpretation
}

\begin{abstract}
JAMES J. BRUDNEY*
The notion that the court that made the ruling which Congress changed went contrary to a common understanding of what the law meant is nonsense .... The truth is that the reach of a law may never be appreciated by the enacting body until it has been passed and put into practice .... That is why constant legislative reappraisal of statutes as construed by the courts . . . is a healthy practice. ${ }^{1}$
\end{abstract}

\section{TABLE OF CONTENTS}

INTRODUCTION

I. CRIMINAL LAW: ROBUST JUDICIAL INVOLVEMENT 893

II. LABOR AND CIVIL RIGHTS: DEFERENCE TO THE POLITICAL

BRANCHES 901

III. THE JUDICIAL VOICE AND INSTITUTIONAL DIALOGUE 911

A. The Court's Interdependent Interpretive Role 911

B. Institutional Comity and Congressional Overrides 913

C. Theoretical Coherence and Practical Complexity 921

CONCLUSION 924

\section{INTRODUCTION}

We are in the midst of an extended debate regarding the proper approach to construing federal statutes. There have been sharp disagreements over whether to privilege or discount key interpretive assets generated by our three branches of government: legislative history, ${ }^{2}$ agency or presidential

* Newton D. Baker-Baker \& Hostetler Chair in Law, The Ohio State University Moritz College of Law. My thanks to Larry Baum, Ruth Colker, Sharon Davies, and Marc Spindelman for very helpful comments on an earlier draft. I am grateful to Jordan Carr and Melanie Oberlin for valuable research assistance and to Jennifer Pursell for excellent secretarial support. The Moritz College of Law and its Center for Interdisciplinary Legal Studies contributed generous financial assistance.

1 William O. Douglas, Legal INSTITUTIONS IN AMERICA 18-19 (Speech at Centennial of Columbia Law School, 1958).

2 Compare ANTONIN SCALIA, A MATTER OF INTERPRETATION: FEDERAL COURTS AND THE LAW 31-37 (1997) (criticizing the use of legislative history), and Alex Kozinski, Should Reading Legislative History Be an Impeachable Offense?, 31 SUFFOLK U. L. REV. 
guidance, ${ }^{3}$ and the canons of construction. ${ }^{4}$ Disputes as to whether these resources should be viewed as constitutionally legitimate, as pragmatically reliable, or as unduly politicized have developed into a form of interpretive branch warfare. ${ }^{5}$

Apart from disagreement among legal scholars, a number of Supreme Court Justices have engaged in at times heated dialogue addressing the pros and cons of textualism or intentionalism, ${ }^{6}$ as well as the virtues and

807, 812-14 (1998) (condemning the misuse of legislative history), with Stephen Breyer, On the Uses of Legislative History in Interpreting Statutes, 65 S. CAL. L. REV. 845, 84761 (1992) (promoting the utility of legislative history), and Charles Tiefer, The Reconceptualization of Legislative History in the Supreme Court, 2000 WIS. L. REV. 205, 230-32 (arguing for legislative history as a reasonable guide to Congress's intent).

${ }^{3}$ See generally William N. Eskridge, Jr. \& Lauren E. Baer, The Continuum of Deference: Supreme Court Treatment of Agency Statutory Interpretations from Chevron to Hamdan, 96 GEO. L.J. 1083 (2008); Thomas W. Merrill \& Kristin E. Hickman, Chevron's Domain, 89 Geo. L.J. 833 (2001); Thomas J. Miles \& Cass R. Sunstein, Do Judges Make Regulatory Policy? An Empirical Investigation of Chevron, 73 U. CHI. L. REV. 823 (2006); Note, Context-Sensitive Deference to Presidential Signing Statements, 120 HARV. L. REV. 597 (2006).

${ }^{4}$ Compare Scalia, supra note 2, at 25-29 (defending canons of construction as effective tools for limiting judicial discretion), and David L. Shapiro, Continuity and Change in Statutory Interpretation, 67 N.Y.U. L. REV. 921, 923-47 (1992) (suggesting that canons promote continuity and neutrality in judicial decision-making), with RICHARD POSNER, THE FEDERAL COURTS: CRISIS AND REFORM 277-82 (1985) (criticizing canons as imputing an unrealistic omniscience to Congress), and Edward L. Rubin, Modern Statutes, Loose Canons and the Limits of Practical Reason: A Response to Farber and Ross, 45 VAND. L. REV. 579, 590 (1992) (arguing that canons "obscure real distinctions, focus attention on subsidiary issues and conceal or displace normative choices.").

${ }^{5}$ In addition to sources cited at notes 2-4, see Green v. Bock Laundry Mach. Co., 490 U.S. 504, 527-28 (1989) (Scalia, J., concurring) (attacking legislative history); W. Va. Univ. Hosp. Inc. v. Casey, 499 U.S. 83, 112-16 (1991) (Stevens, J., dissenting) (defending legislative history); Orrin Hatch, Legislative History: Tool of Construction or Destruction, 11 HARV. J.L. \& PUB. POL'Y 43, $45-48$ (1988) (defending legislative history); United States v. Mead Corp., 533 U.S. 218, 235-38, 240-56 (2001) (Souter, J., and Scalia, J., disagreeing over scope and standards for agency deference); Memorandum from Samuel A. Alito, Jr., Deputy Ass't Att'y Gen., Office of Legal Counsel, U.S. Dep't of Justice, to the Litig. Strategy Working Group (Feb. 5, 1986), available at $\mathrm{http} / / / \mathrm{www}$.archives.gov/news/Samuel-alito/accession-060-89-269/acc060-89-269-box6-

SG-LSWG-Feb1986.pdf (defending Presidential signing statements from within Dept. of Justice); EEOC v. Arabian Am. Oil Co., 499 U.S. 244, 248, 260-61 (1991) (Rehnquist, J., and Marshall, J., disagreeing over weight and meaning of a key substantive canon).

${ }^{6}$ See, e.g., Conroy v. Aniskoff, 507 U.S. 511,518 n.12 (1993) (Stevens, J., majority, debating with Scalia, J., concurring); United States v. Thomson/Center Arms Co., 504 U.S. 505, $516 \mathrm{n.8}$ (1992) (Souter, J., majority, debating with Scalia, J., concurring); Wis. Pub. Intervenor v. Mortier, 501 U.S. 597, 610-12 n.4 (1991) (White, J., majority, debating with Scalia, J., concurring). 
limitations of Chevron deference. ${ }^{7}$ Justice Ginsburg has remained substantially removed from these judicial exchanges. Given that she has authored her share of majority opinions construing federal statutes, her comparative reticence on matters of interpretive methodology is unusual although not unique. On occasion, Justice Ginsburg's silence conjures up the image of a bemused bystander, as when her fellow Justices savage one another in concurring opinions while her opinion for the Court sails serenely above that fray. ${ }^{8}$

Despite her apparent decision not to articulate a philosophy, Justice Ginsburg has adopted her own approach to the challenge of interpreting federal statutes. This Article examines that approach by focusing on four opinions construing federal criminal statutes and three opinions interpreting labor relations and anti-discrimination laws. These seven opinions-five majorities and two dissents-are not offered as an empirically representative cross-section of Ginsburg's work in the area of statutory interpretation. They are, however, fairly illustrative ${ }^{9}$ of her effort to position the Court as a participant in an ongoing dialogue with the two other branches.

For Justice Ginsburg, neither textualism nor intentionalism ${ }^{10}$ provides a dominant orientation. Rather, her reliance on certain interpretive resources

${ }^{7}$ See, e.g., Mead Corp., 544 U.S. at 235-38, 240-56 (Souter, J., majority, debating with Scalia, J., dissenting); INS v. Cardoza-Fonseca, 480 U.S. 421,432 n.12 (1987) (Stevens, J., majority, debating with Scalia J., concurring); Christensen v. Harris County, 529 U.S. 576, 591 (2000) (Scalia, J., concurring, debating with Breyer, J., dissenting).

8 See Bank One Chi., N.A. v. Midwest Bank \& Trust Co., 516 U.S. 264, 270-75 (Ginsburg, J., majority); id. at 276-78 (Stevens, J., concurring); id. at 279-81 (Scalia, J., concurring).

9 Justice Ginsburg authored over 125 majority opinions and 80 dissents during her first fifteen years on the Court, from the 1993 through the 2007 Terms. Of her majorities construing substantive statutory language, I have identified nine that addressed federal criminal or sentencing provisions and ten that involved interpretation of labor relations or civil rights laws. I chose to analyze majorities and dissents in which Ginsburg was reasonably explicit about her adoption or rejection of interpretive resources. For other criminal law majority opinions in which Ginsburg relies heavily on text and canons, see Bates v. United States, 522 U.S. 23 (1997); Logan v. United States, 552 U.S. 23 (2007). For other civil rights opinions in which Ginsburg relies heavily on legislative history and/or agency deference, see Gisbrecht v. Barnhart, 535 U.S. 789 (2002); Ledbetter v. Goodyear Tire \& Rubber Co., 550 U.S. 618, 643 (2007) (Ginsburg, J., dissenting).

10 Textualist judges and scholars contend that courts should devote their energies to analyzing and explaining the language enacted into law and should avoid reliance on the unenacted intentions expressed by various congressional subgroups. See John F. Manning, Justice Scalia and the Legislative Process, 62 N.Y.U. ANN. SURV. AM. L. 33, 36-41 (2006). Intentionalist judges and scholars maintain that statutes are the end product of a complex communicative process, and that courts should seek to discern and apply the intent expressed by key legislative subgroups during that process in order to clarify or 
varies depending on how she views the Court's role as an interstitial actor. In the criminal law area, Ginsburg opinions make primary use of languagebased analysis and of two substantive canons that operate to constrain the scope of text, while downplaying contextual evidence of congressional or Executive Branch intent. By contrast, her labor and anti-discrimination opinions-although they begin with textual analysis-rely heavily on legislative history and purpose as well as on agency deference. Such notable differences in interpretive approach may reflect in part Justice Ginsburg's underlying policy preferences. A more important lesson of these opinions, though, is how they reflect her view of the Court's appropriate institutional interaction with the political branches.

When construing the meaning and scope of criminal law statutes, Justice Ginsburg advances a fairly muscular institutional role for the Court. She relies on close textual readings combined with judicial policy norms like the rule of lenity and the anti-preemption canon to shape an interpretive dialogue with Congress and the Executive. Her position may well signify both a constitutionally informed ${ }^{11}$ policy concern for the powerless position of criminal defendants in regular political discourse and an expectation that the political branches are quite capable of producing effective responses to criminal law majority opinions with which they disagree. But when it comes to labor relations and civil rights, Ginsburg seems to regard the Court as a more junior partner in the lawmaking enterprise. Her willingness to rely on contextual resources produced by Congress and the Executive suggests a level of deference to these branches that is missing from her interpretive approach in criminal law. This more deferential stance may in turn signal both a greater comfort level about how interest group politics operate in a civil regulatory setting and greater skepticism regarding Congress's ability to correct or respond to any constraining constructions imposed by the Court.

Part I of this Article addresses Justice Ginsburg's approach in criminal law, focusing on her majority opinions in Ratzlaf v. United States, ${ }^{12}$ Cleveland $v$. United States, ${ }^{13}$ and Jones $v$. United States, ${ }^{14}$ and her dissenting opinion in Muscarello v. United States. ${ }^{15}$ Part II discusses the Ginsburg

amplify inconclusive text. See James J. Brudney, Intentionalism's Revival, 44 SAN DIEGo L. REV. 1001, 1004-12 (2007).

${ }^{11}$ See generally John Calvin Jeffries, Jr., Legality, Vagueness, and the Construction of Penal Statutes, 71 VA. L. REV. 189, 202-21 (1985) (discussing separation of powers, notice, and rule of law justifications for relatively strict interpretation of criminal statutes).

12510 U.S. 135 (1994).

13531 U.S. $12(2000)$.

14529 U.S. 848 (2000).

15524 U.S. 125, 139 (1998) (Ginsburg, J., dissenting). 
approach in labor and civil rights law, as illustrated by her dissent in NLRB $v$. Health Care \& Retirement Corp., ${ }^{16}$ her majority opinion in Holly Farms Corp. v. NLRB, ${ }^{17}$ and her majority opinion in Olmstead v. L.C. ex rel. Zimring. ${ }^{18}$ Part III attempts to reconcile these quite distinct methodological approaches by invoking Ginsburg's view of the Court as an interstitial actor in our separation-of-powers scheme.

\section{CRIMINAL LAW: ROBUST JUdICIAL INVOLVEMENT}

Ratzlaf v. United States, ${ }^{19}$ decided during Justice Ginsburg's initial Term, presented the issue of what the government must prove to convict an individual of "willfully violating" the anti-structuring provision of the Money Laundering Control Act of $1986 .{ }^{20}$ Acting pursuant to a 1970 statute, the Secretary of the Treasury had required financial institutions to report currency transactions of more than $\$ 10,000.21$ In an effort to deter circumvention of this mandate, Congress in 1986 prohibited any person from structuring a financial transaction "for the purpose of evading the reporting requirements" of the earlier statute, ${ }^{22}$ and also specified criminal penalties for anyone "willfully violating" the new prohibition on structuring. ${ }^{23}$ Ratzlaf had paid off $\$ 160,000$ in gambling debts by purchasing cashiers' checks for just under $\$ 10,000$ from a series of banks. He admitted this was no accident: he had intentionally structured the cash transactions for the purpose of avoiding the banks' obligation to report them, but he denied knowing that his own structuring activity was unlawful. ${ }^{24}$

The Supreme Court reversed Ratzlaf's conviction and in doing so rejected the approach taken by ten circuits that had addressed this issue. ${ }^{25}$ Writing for a five-to-four majority, Justice Ginsburg held there could be no conviction unless a jury finds that the person who structured the transaction

16511 U.S. 571, 584 (1994) (Ginsburg, J., dissenting).

17517 U.S. 392 (1996).

18527 U.S. 581 (1999).

19510 U.S. 135 (1994).

20 Pub. L. No. 99-570, tit. I, subtit. H, § 1354, 100 Stat. 3207-22 (1986) (codified at 31 U.S.C. $\$ 5324$ (2006)); see also 510 U.S. at 139-40.

21 See 510 U.S. at 138-39.

2231 U.S.C. $\$ 5324$ (2006); see 510 U.S. at 139-40.

23 See 510 U.S. at 140.

24 See id. at 137-38.

25 See id. at 152-53 \& n.3 (Blackmun, J., dissenting) (citing to cases from ten circuits and observing that the only circuit to have come out differently allowed "reckless disregard" of the anti-structuring requirements to support a conviction). 
had specific knowledge that structuring itself was illegal, not simply that evading the banks' reporting requirements was unlawful activity. ${ }^{26}$ Ginsburg relied heavily on the textual integrity canon ${ }^{27}$ to avoid interpretations that render certain words or phrases as surplusage. She reasoned that under the government's approach, the phrase "willfully violating" would have added nothing to the offense because conviction required no more than proof of the first scienter requirement in the law-a "purpose of evading the reporting requirements." 28 Further, the government's position might criminalize currency structuring that was "not inevitably nefarious," such as a small business keeping deposits below $\$ 10,000$ to avoid the burdens of an IRS audit or an individual reducing deposits to keep his wealth status secret from a former spouse. ${ }^{29}$

Justice Ginsburg concluded that because the text was so clear, she would not resort to legislative history to "cloud" the Court's textual analysis. ${ }^{30}$ Importantly, she also observed that even if the "willfulness" requirement were ambiguous, principles of lenity would compel resolution in favor of the defendant. ${ }^{31}$

The majority analysis in Ratzlaf was hotly contested. Justice Blackmun in dissent contended that the term "willful" in criminal law was commonly used less restrictively than the majority suggested, and at a minimum the text was therefore ambiguous. ${ }^{32}$ Blackmun's review of the legislative history provided strong evidence that Congress in 1986 meant to criminalize individual behavior like Ratzlaf's - and that Congress was not even aware of, much less worried about, any need for a second scienter showing. ${ }^{33}$ The dissent relied in its analysis on two committee reports and also on hearing testimony from the Deputy Attorney General. ${ }^{34}$

The Ratzlaf decision was questioned by criminal law practitioners and academics as well as legislation scholars. ${ }^{35}$ It also drew fire from Congress,

26 See id. at $140-49$.

27 See William N. Eskridge et Al., CASES aNd MATERIALS ON LegiSlation app. $B$, at 21 (4th ed. 2007) (discussing textual integrity canon, or the Whole Act Rule).

28510 U.S. at $140-41$.

29 Id. at $144-45$.

${ }^{30} \mathrm{Id}$. at $147-48$.

${ }^{31} \mathrm{Id}$. at $148-49$.

32 Id. at $151-56$.

33 See id. at 157-59.

${ }^{34}$ Ratzlaf, 510 U.S. at 158-59 \& n.10.

35 See Kathryn Keneally, Supreme Court Raises "Specific Intent" Threshold for Some Criminal Violations, 81 J. TAX'N 44, 47 (1994) (questions from litigator); Sharon L. Davies, The Jurisprudence of Willfulness: An Evolving Theory of Excusable 
which overrode the Court within months as part of a larger statute regulating banking practices. ${ }^{36}$ Although judges-like the rest of us-do not necessarily embrace criticism, I doubt that Justice Ginsburg was overly disturbed by Congress's prompt, business-like reaction. Having invoked Justice Holmes' gloss on the rule of lenity-that "legislatures and not courts should define criminal activity" 37 - Ginsburg may have anticipated that Congress would act to vindicate the Justice Department's position by expressing more clearly its legislative policy preference. The speed of Congress's response, however, may have educated the new Justice to expect that in future instances, Congress might be prepared to clarify its intent on criminal enforcement in response to Court interpretations it views as unduly restrictive.

In Cleveland $v$. United States, ${ }^{38}$ another white collar crime case decided seven terms later, the issue was whether defendants who made false statements when applying for a Louisiana state license to operate video poker machines had deprived the state of "property" within the meaning of the federal mail fraud statute. ${ }^{39}$ That statute prohibits use of the mails to further "any scheme or artifice to defraud, or for obtaining money or property by means of false or fraudulent pretenses." 40 Justice Ginsburg, for a unanimous Court, held that issuance of a state license was not a relinquishment of "property" under the federal law. ${ }^{41}$

The Court relied heavily on the analysis of "property" it had set forth over a decade earlier in McNally $v$. United States. ${ }^{42}$ The Court in McNally held that patronage schemes depriving citizens of their intangible right to honest services were not covered under Section 1341 as deprivations of property. ${ }^{43}$ Justice Ginsburg recognized that Congress had partially

Ignorance, 48 DUKE L.J. 341, 374-81 (1998) (questions from criminal law scholar); William N. Eskridge, Jr. \& Philip P. Frickey, The Supreme Court, 1993 TermForeword: Law as Equilibrium, 108 HARV. L. REV. 26, 58-60 (1994) (questions from legislation scholars).

36 See Riegle Community Development and Regulatory Improvement Act, Pub. L. No. 103-325, $\S 411,108$ Stat. 2160, 2253 (1994). For evidence that Congress was acting to override Ratzlaf, see, for example, H.R. REP. No. 103-438, at 13, 22 (1994); 140 CONG. REC. 5572 (1994) (statement of Rep. Neal).

37510 U.S. at 148-49 (quoting McBoyle v. United States, 283 U.S. 25, 27 (1931) (Holmes, J.)).

38531 U.S. $12(2000)$.

3918 U.S.C. $\$ 1341$ (2006).

40 Id. (emphasis added).

41 See Cleveland, 531 U.S. at 18-27.

42483 U.S. 350 (1987).

${ }^{43} I d$. at 356-60. 
overridden $M c N a l l y$ the following year,44 by specifying that a "scheme or artifice to defraud" includes a scheme or artifice to deprive someone of the intangible right to honest services. ${ }^{45}$ But she viewed it as "significant" that Congress addressed only this intangible right, and did not otherwise question the McNally Court's reasoning that Section 1341 was limited to depriving someone of proceeds in money or property. ${ }^{46}$ Ginsburg went on to determine that Louisiana did not part with any "property" when issuing a license. Rejecting various arguments from the Department of Justice, she concluded that the state's interests in this licensing setting were regulatory as part of its ordinary exercise of police powers. ${ }^{47}$

In addition to reiterating the Court's prior textual analysis focused on traditional concepts of "property," Justice Ginsburg invoked two substantive canons in support of the Court's construction. She again relied on the rule of lenity, emphasizing that any ambiguity as to the meaning of the word "property" should be resolved against the government. 48 She also invoked the anti-preemption canon and its special applicability in the traditionally state law area of criminal enforcement, reasoning that the Court should not "approve a sweeping expansion of federal criminal jurisdiction in the absence of a clear statement by Congress." 49 Relatedly, the majority, aware of Congress's response to the Court's prior interpretation of this same statute, effectively invited further institutional dialogue: "Again, as we said in McNally, if Congress desires to go further, it must speak more clearly than it has." 50

Justice Ginsburg in Cleveland anticipates with apparent equanimity the prospect of an override by Congress. She recognizes that Congress overrode the Court on this very provision in McNally, and she also is aware that Congress overrode her own narrowing construction of a separate criminal provision in Ratzlaf. ${ }^{51}$ Her composed stance echoes that of Justice White, whose seat she filled on the Court, and whose memorandum to the Conference accompanying the McNally opinion remarked on the "saving grace in statutory construction cases . . . that Congress may have its way if it

44 See Cleveland, 531 U.S. at 19-20.

45 Anti-Drug Abuse Act of 1988, Pub. L. No. 100-690, § 7603(a), 102 Stat. 4181, 4508 (1988) (codified at 18 U.S.C. $§ 1346(2006)$ ).

46 Cleveland, 531 U.S. at 19-20.

47 Id. at 20-24.

48 See id. at 25.

49 Id. at 24.

50 Id. at 20 (internal quotations omitted).

${ }^{51}$ See supra text accompanying note 36. 
does not like the product of our work." 52 Although Congress has not yet taken action in Cleveland, the Senate Judiciary Committee approved a bipartisan bill in the last Congress that would have overridden the Court's holding 53 and a similar bill was introduced at the start of the current Congress. ${ }^{54}$

The third Ginsburg majority opinion construing a federal criminal statute is Jones $v$. United States, ${ }^{55}$ which involved the crime of arson. The defendant was convicted under the federal arson statute for throwing a Molotov cocktail into a private residence in Indiana. ${ }^{56}$ The court of appeals accepted the Justice Department's jurisdictional argument that this home was "used in interstate commerce" under the statute because the home served as collateral to obtain a mortgage from an out-of-state lender, it was insured by an out-ofstate company, and it received natural gas from out-of-state sources. ${ }^{57}$ Writing for a unanimous Court, Justice Ginsburg reversed the conviction: she construed "used" to require that a private residence be actively employed as part of a commercial venture, not simply serve as a passive conduit for various commercial contacts. ${ }^{58}$

Ginsburg once again relied on a close textual reading. She invoked the ordinary meaning of the word "used" as having an active connotation. 59 She also relied on the presumption against surplusage, reasoning that because interstate energy sources are consumed in virtually all American homes, the additional limiting language included in the statutory provision would have no meaning under the government's argument. ${ }^{60}$

52 See Memorandum of Justice White, on file in The Thurgood Marshall Papers, Library of Cong., Madison Bldg., box 423, folder 3, Nos. 86-234 and 86-286 (regarding McNally), quoted in ESKRIDGE ET AL., supra note 27, at 900.

53 See S. 1946, 110th Cong. $\$ 3$ (2007) (introduced by Sens. Leahy, Cornyn, and Sessions); S. REP. No. 110-239, at 8 (2007) (explaining how bill would override Cleveland holding).

54 See 155 CONG. REC. S56-57 (daily ed. Jan. 6, 2009) (statement of Sen. Leahy discussing S. $49, \S 3$, introduced by Sens. Leahy and Cornyn).

55529 U.S. 848 (2000).

$56 \mathrm{See}$ id. at 851 . The statutory provision, 18 U.S.C. $\$ 844(\mathrm{i})$ (2006), criminalizes malicious damage or destruction, by means of fire or explosives, of "any building ... used in interstate or foreign commerce or in any activity affecting interstate or foreign commerce."

57 See 529 U.S. at 855.

58 See id. at 852-59.

59 See id. at 855-56.

${ }^{60} \mathrm{See} i \mathrm{~d}$. at 857 (referring to requirement that building be used in any commerceaffecting activity). 
As in Ratzlaf and Cleveland, the Court in Jones concluded that the text was unambiguous-despite an even split among the six circuits to have addressed this issue. ${ }^{61}$ And as in her earlier majorities, Justice Ginsburg went on to conclude that her textual analysis was "additionally reinforced by other interpretive guides."62 She invoked both the rule of lenity and the presumption against altering the traditional federal-state balance in criminal law to emphasize that even if the language were ambiguous, it should be construed against the Department of Justice. ${ }^{63}$

In a brief concurrence, Justice Stevens praised the majority's reasoning while noting that the defendant's criminal offense under state law would have resulted in a far shorter period of imprisonment than he had received from the federal trial court. ${ }^{64}$ Stevens then reiterated the majority's implicit invitation to Congress to speak more clearly if it wished to federalize this conduct traditionally regulated by the states. ${ }^{65}$

The final criminal law decision, Muscarello v. United States, ${ }^{66}$ features Justice Ginsburg writing a dissent. The case dealt with the enhanced prison sentence that attaches to carrying a firearm during a drug-trafficking offense. The issue presented was whether the phrase "carries a firearm" triggered a mandatory sentence when the defendant knowingly placed a gun in his glove compartment for protection in relation to the drug offense, or only if the defendant had been carrying a firearm on his person while committing the crime. ${ }^{67}$ The Court ruled five-to-four for the broader meaning of "carries" urged by the government; Justice Ginsburg spoke for the four dissenters. ${ }^{68}$

${ }^{61}$ See id. at 852 n. 2 (listing three circuits on each side). In this instance, as in Ratzlaf, Justice Ginsburg seemed comfortable insisting on an absence of ambiguity in the face of substantial appellate court analysis to the contrary. Cf. Casey, 499 U.S. 83, 98-99 (Scalia, J., majority) (insisting that statutory language was plain and unambiguous and therefore legislative history was irrelevant); id. at 112-13 (Stevens, J., dissenting) (criticizing majority for "put[ting] on its thick grammarian's spectacles and ignor[ing] the available evidence of congressional purpose.").

62529 U.S. at 858.

${ }^{63}$ See id. Ginsburg also invoked the canon of avoiding constitutional questions, referencing the Court's recent Lopez decision that identified limits on the reach of Congress's Commerce Clause jurisdiction. See id. at 857-58. But given that Justices Ginsburg and Stevens (who concurred here) were Lopez dissenters, this unanimous opinion is best understood as a statutory construction decision. See also id. at 860 (Thomas, J., concurring) (reserving constitutional questions about arson statute).

$64 \mathrm{See}$ id. at 859 (comparing ten years for state offense with thirty-five years for federal offense).
${ }^{65}$ See id. at 859-60.
66524 U.S. 125 (1998).
${ }^{67}$ See id. at 126-27.
${ }^{68}$ See id. at $139-50$. 
Justices Breyer (for the majority) and Ginsburg disagreed with respect to a wide array of interpretive resources. On the ordinary and dictionary meanings of "carries," each side made respectable arguments and one could infer that the word itself was somewhat ambiguous in this setting. ${ }^{69}$ With respect to legislative history and purpose, though, the majority had the stronger position. Justice Breyer relied on floor statements from several House members including the bill's chief sponsor that the provision sought "to persuade a man who is tempted to commit a federal felony to leave his gun at home." 70 The majority also invoked a number of additional statements indicating that members understood the word "carries" to have a scope well beyond bearing a gun on one's person. ${ }^{71}$ Justice Ginsburg's effort to rebut the majority's legislative history arguments was brief and not overly persuasive. ${ }^{72}$ Moreover, the specific legislative history relied on by the majority comported with the statute's broader purpose, previously described by the Court as "an effort to combat the dangerous combination of drugs and guns."73

Of special interest is the debate in Muscarello between the majority and dissent regarding the rule of lenity. For Justice Breyer, most penal statutes contain some ambiguity, but principles of lenity do not come into play in the vast majority of such cases. Rather, the rule applies only as a tiebreaker in instances of "grievous ambiguity or uncertainty" where a court "can make no more than a guess as to what Congress intended." 74 By contrast, Justice Ginsburg regards the rule of lenity as a presumption, not merely a tiebreaker. Unless the text, structure, and legislative history "establish that the Government's position is unambiguously correct," courts must resolve the ambiguity in favor of the criminal defendant. ${ }^{75}$

Putting aside differences between majority and dissent as to whether the ambiguity in Muscarello is run-of-the-mill or grievously exceptional, what stands out is Justice Ginsburg's insistence that the rule of lenity shifts the

${ }^{69}$ Compare id. at 127-31 (majority reliance on definitions from five dictionaries and ordinary usage examples from inter alia King James Bible and Herman Melville), with id. at 142-45 (dissent reliance on definitions from two dictionaries and ordinary usage examples from inter alia King James Bible, Rudyard Kipling, and Theodore Roosevelt).

${ }^{70} \mathrm{Id}$. at 132 (quoting remarks of Rep. Poff and two other House supporters) (emphasis added).

${ }^{71}$ See Muscarello, 524 U.S. at 133-34 (relying on remarks from six House members).

72 See id. at 148 n. 12.

73 See id. at 132 (quoting Smith v. United States, 508 U.S. 223, 240 (1993) (internal quotation marks omitted)).

${ }^{74}$ Id. at 138-39 (internal citations omitted).

${ }^{75}$ Id. at 148 (internal citations omitted). 
burden of clarity to the political branches. Under the Ginsburg approach, there can be no prosecution when even a modicum of ambiguity exists in a criminal statute. Imposing on Congress the obligation to be "decisively clear"76 in text is appropriate because Congress--supported by the Executive -is in a relatively strong position to modify or override the Court's construction. Indeed Congress had recently overridden the Court's restrictive interpretation of the phrase "uses a firearm" in this same sentenceenhancement provision. ${ }^{77}$

The four criminal law cases summarized above construe two statutory provisions covering white collar crime and two that address more traditional street crime. Justice Ginsburg's interpretive stance favoring the criminal defendant in each decision is consistent with her broader ideological orientation toward the rights and interests of society's disadvantaged or dispossessed. ${ }^{78}$ Pro-defendant outcomes, however, are hardly Ginsburg's uniform position when authoring opinions that construe federal criminal statutes. ${ }^{79}$ At the same time, Ginsburg applies her reliance on close textual analyses plus constitutionally grounded substantive canons equally to white collar defendants and those accused of street crimes. The fact that her interpretive approach yields pro-defendant outcomes in all four decisions is intriguing, given that many other Justices-liberal and conservative--vote very differently when it comes to white collar as opposed to non-white collar criminal cases. ${ }^{80}$ Moreover, the distribution of Justices in these four cases does not mirror traditional liberal-conservative fault lines. ${ }^{81}$

${ }^{76} \mathrm{Id}$.

77 See Pub. L. No. 105-386, 112 Stat. 3469 (codified as amended at 18 U.S.C. $\S 924(\mathrm{c}))$. The 1998 statute overrode the Court's unanimous decision in Bailey v. United States, 516 U.S. 137 (1995). See H.R. REP. No. 105-344, at 6 (1997).

${ }^{78}$ See generally Deborah Jones Merritt \& David M. Lieberman, Ruth Bader Ginsburg's Jurisprudence of Opportunity and Equality, 104 COLUM. L. REV. 39 (2004).

${ }^{79}$ See, e.g., Logan v. United States, 552 U.S. 23 (2007) (majority opinion affirming enhanced sentence based on statutory analysis); Lopez v. Davis, 531 U.S. 230 (2001) (majority opinion affirming denial of sentence reduction based on statutory analysis); Bates v. United States, 522 U.S. 23 (1997) (majority opinion affirming criminal conviction based on statutory analysis).

${ }^{80}$ See J. Kelly Strader, The Judicial Politics of White Collar Crime, 50 HaSTINGS L.J. 1199, 1217, 1229-30 (1999) (reporting that for Supreme Court criminal law decisions from 1971 to 1994, Justices Brennan and Marshall voted for defendants far less often in white collar criminal cases, while Justices O'Connor, Powell, Rehnquist, and Scalia voted for defendants far more often in white collar criminal cases-for Chief Justice Rehnquist the difference was $62 \%$ v. $8 \%$ and for Justice Scalia it was $82 \%$ v. $7 \%$ ); Lawrence Baum \& Wendy Watson, Policy Preferences and Social Interests in the Supreme Court: Voting in Criminal Cases 14, 15-18 (Sept. 27, 1999) (unpublished manuscript, on file with author) (reporting that in criminal cases from 1975 to 1985 , 
Apart from any ideological explanation, Justice Ginsburg's reliance on close textual readings, her discounting of legislative history, and her emphasis on two key substantive canons likely reflect the presence of strong institutional considerations. In this criminal law setting, Ginsburg turns to judicial policy norms disfavoring overzealous prosecution and the federalization of what she regards as a traditionally state law field. These two substantive canons play a central role in the Court's ongoing conversation with Congress and the Executive on matters of statutory interpretation. Invoking one or both of these canons in each of her four opinions, Justice Ginsburg effectively invites Congress to respond by clarifying its policy preferences. She seems convinced-based on the recent legislative track record in this area - that Congress will do so if in fact it wants to expand the scope of federal criminal jurisdiction and the extent of defendants' exposure to federal prosecution.

\section{LABOR AND CIVIL RIgHTS: DEFERENCE TO THE POLITICAL BRANCHES}

Justice Ginsburg has been centrally involved in two decisions interpreting provisions of the National Labor Relations Act (NLRA or Act). ${ }^{82}$ In NLRB v. Health Care \& Retirement Corp. ${ }^{83}$ decided during her first Term on the Court, the issue was how broadly to construe the supervisory employee exemption from NLRA coverage. Four licensed practical nurses at a nursing home were responsible for monitoring and directing the work of aides on evenings and weekends in the interest of residents' care and wellbeing. ${ }^{84}$ The National Labor Relations Board (NLRB or Board) held that these four nurses were covered employees rather than excluded supervisors

liberal Justices were less favorable toward business defendants than toward "ordinary" criminal defendants while conservative Justices were more favorable).

81 Two decisions-Cleveland and Jones-are unanimous, but the Senate Judiciary Committee views Cleveland as overly liberal (see supra notes 53-54 and accompanying text) while a number of legal scholars regard Jones as distinctly conservative. See, e.g., Craig M. Bradley, Federalism and the Federal Criminal Law, 55 HASTINGS L.J. 573, 583-86 (2004); George D. Brown, Constitutionalizing the Federal Criminal Law Debate: Morrison, Jones, and the ABA, 2001 U. ILL. L. REV. 983, 1009-11. As for the two closely divided decisions, Justice Ginsburg is joined in Ratzlaf by two liberals (Justices Stevens and Souter) and two conservatives (Justices Kennedy and Scalia), and in Muscarello her dissent is joined by one liberal (Justice Souter) and two conservatives (Chief Justice Rehnquist and Justice Scalia).

8229 U.S.C. $\S \S 151-69(2000)$. I use the term "NLRA" to refer to the original 1935 statute as amended in 1947 and 1959.

83511 U.S. 571 (1994).

${ }^{84}$ See id. at 574-75. 
under the Act. ${ }^{85}$ The Supreme Court rejected the Board's position by a fiveto-four vote; Justice Ginsburg authored the dissent. ${ }^{86}$

Justice Kennedy for the majority concluded that the Board's well-settled interpretation of the definition of "supervisor" was at odds with the plain language of the Act. The definition encompasses individuals with authority "in the interest of the employer" to hire, discipline, discharge, or responsibly direct other employees. ${ }^{87}$ The Board had long viewed this phrase as covering the interests of the employer in terms of personnel relations but not professional performance. ${ }^{88}$ For the majority, the ordinary meaning of the phrase was much broader-it included all acts by an employee "within the scope of employment or on the authorized business of the employer." 89 Justice Kennedy acknowledged that this broad reading of excluded supervisors might create tension with the Act's inclusion of professionals as employees, but he dismissed the Board's effort to resolve that tension as a distortion of the statutory language..$^{90}$ The majority also discounted any effort to rely on the Act's legislative history, characterizing the committee report language invoked by the Board as isolated and without authority. ${ }^{91}$

Justice Ginsburg's dissent relied heavily on the views expressed by the two other branches. She found the textual definition of "supervisor" clearly relevant but ultimately insufficient given the tension between Congress's exclusion of supervisors and its simultaneous inclusion of professionals. ${ }^{92}$ Congress had added the exclusion of supervisors in 1947 to override a Supreme Court decision that deemed them to be covered employees absent express language to the contrary. ${ }^{93}$ Justice Ginsburg paid close attention to the legislative history accompanying this 1947 language; she found that several documents reflected an intent to limit the scope of the new exclusion to front line managers who had the right to hire, fire, discipline, or effectively to recommend such actions. ${ }^{94}$ Relatedly, Ginsburg emphasized that Congress had added protection for professionals as part of the same statutory changes,

${ }^{85}$ See id. at 575.

86 See id. at 584-99.

${ }^{87} \mathrm{See} i d$. at 573 (quoting 29 U.S.C. $\$ 152(11)$ ).

88 See Health Care, 511 U.S. at 574.

${ }^{89} \mathrm{Id}$. at 578.

${ }^{90} \mathrm{See}$ id. at 581.

91 See id. at 581-82.

92 See id. at 584-85.

${ }^{93}$ See id. at 586-87.

${ }^{94}$ See Health Care, 511 U.S. at 587-88 \& n.4, 589, 595 n.14 (relying on Senate committee report, Conference report, and floor statement from leading House supporter). 
and this addition necessarily tempered the scope of the supervisor definition. ${ }^{95}$

Justice Ginsburg also observed that over a twenty-year period, the NLRB had harmonized Congress's twin policies-including professionals while excluding supervisors - through a series of decisions covering a wide array of white collar employees. ${ }^{96}$ She found the Board's line of decisions, including this one, to be fully rational and consistent with the Act and therefore deserving of deference. ${ }^{97}$ Ginsburg's dissent warned that the majority opinion would have substantial implications, excluding virtually all professionals from the Act's protections. ${ }^{98}$ She regarded this holding as indefensible largely because it undermined the policy positions adopted by Congress and the Executive.

The decision in Health Care was highly controversial; it has been sharply criticized by scholars and practitioners as well as labor unions. ${ }^{99}$ The Court has reinforced its holding since 1994, further limiting coverage of health care professionals in a closely divided decision. ${ }^{100}$ Thirteen years after Health Care, a bill was introduced to override the Court's ruling, but the proposal made little progress ${ }^{101}$ and future prospects for such labor law reform are far from promising. ${ }^{102}$

\section{See id. at 588 .}

96 See id. at 589-92 (discussing Board decisions concerning supervisory status of inter alia doctors, pharmacists, librarians, social workers, architects, and engineers).

97 See id. at 590-92, 598-99.

98 See id. at 598-99.

99 See, e.g., Richard J. Pierce, Jr., The Supreme Court's New Hypertextualism: An Invitation to Cacophony and Incoherence in the Administrative State, 95 COLUM. L. REV. 749, 758-59 (1995) (criticism from legal scholar); Charles J. Morris, A Blueprint for Reform of the National Labor Relations Act, 8 ADMIN. L.J. AM. U. 517, 558-60 (1994) (same); Joseph R. Grodin, Report on the 1993-94 Supreme Court Labor and Employment Law Term, 10 LAB. LAW. 693, 697-99 (same); Edwin A. Keller, Jr., Death by Textualism: The NLRB's "Incidental to Patient Care" Supervisory Status Test for Charge Nurses, 46 AM. U.L. REV. 576, 599-617 (criticism from legal practitioner); $A F L$ CIO, Employers Spar Over Reform of Labor Laws Before Dunlop Commission, Daily Lab. Rep. (BNA) at D-25 (Sept. 9, 1994) (criticism by Lewis Maltby of National Task Force on Civil Liberties in the Workplace); ANA Convention Calls for Legislation to Overturn Supreme Court Decision, Daily Lab. Rep. (BNA) at D-23 (June 23, 1994) (criticism from American Nurses Association).

100 See NLRB v. Ky. River Cmty. Care, 532 U.S. 706 (2001). The Bush Labor Board recently applied the lessons of Health Care and Kentucky River to restrict coverage of nurses in particular settings. See Oakwood Health Care, Inc., 348 N.L.R.B. 686 (2006).

101 See H.R. 1644, 110th Cong. (2007); S. 969, 110th Cong. (2007) (introduced Mar. 22, 2007). These identically worded bills would have modified the definition of 
Justice Ginsburg's second contribution to NLRA jurisprudence, Holly Farms Corp. v. $N L R B,{ }^{103}$ came down two Terms later. This case also involved a coverage issue-whether the Act's exemption for agricultural laborers applied to individuals who collect for slaughter chickens raised by independent "growers" and transport the chickens to their employer's foodprocessing plant. ${ }^{104}$ Writing for the majority in another five-to-four case, Ginsburg ruled that these workers were covered employees rather than exempt agricultural laborers. ${ }^{105}$

The Court began by observing that the NLRA contained no definition of "agricultural laborer."106 Congress had long instructed the Board to rely on the definition of "agriculture" in the Fair Labor Standards Act (FLSA), a definition that included considerable detail and specificity. ${ }^{107}$ But Justice Ginsburg found the FLSA definition and the Department of Labor's implementing regulations to be inconclusive in this setting. ${ }^{108}$

Her analysis turned instead to the legislative history accompanying Congress's 1946 determination that "agricultural laborer" should be linked to the FLSA definition. She noted that the initial House version had incorporated a broad definition borrowed from the Social Security Act, but

\footnotetext{
"supervisor" to require that an employee must spend the majority of her time in a supervisory capacity; they also proposed to delete the phrase "responsibly to direct" from the definition. For evidence that the bills' intent was to override Health Care and its progeny, see Are NLRB and Court Rulings Misclassifying Skilled and Professional Employees as Supervisors?: Hearing Before the Subcommittee on Health, Employment, Labor and Pensions to Consider H.R. 1644, the ReEmpowerment of Skilled and Professional Employees and Construction Tradesworkers (RESPECT) Act, 110th Cong. 9-16 (2007) (testimony of Sarah M. Fox); 153 Cong. Rec. S3615 (daily ed. Mar. 22, 2007) (remarks of Sen. Dodd). A review of the Bill Summary and Status for H.R. 1644 at the Library of Congress's Thomas Website (http://thomas.loc.gov), carried out on October 22, 2008, indicates that the House bill was reported out of committee on a straight party line vote in September 2007, but that no committee report was ever filed and no floor action scheduled. The office of Rep. Robert E. Andrews, chief sponsor of H.R. 1644, confirmed that the bill passed out of committee with no report. Interview by Melanie Oberlin, Library Reference Specialist at Moritz College of Law, with congressional aide to Rep. Andrews (Oct. 22, 2008). The Senate bill was referred to committee; no action was ever taken.

102 Congress has not amended the NLRA in any substantial way for fifty years. See infra note 182 and accompanying text (discussing congressional gridlock).

103517 U.S. 392 (1996).

104 See id. at 394-95.

105 See id. at 397-409.

106 See id. at 397.

107 See id. at 397-98 (discussing annual riders to Appropriations Acts for the NLRB and quoting definition from 29 U.S.C. $\S 203(\mathrm{f})$ ).

108 See Holly Farms, 517 U.S. at 405-06.
} 
lawmakers in the Senate objected that this would exclude a large number of food processing employees. ${ }^{109}$ The final version adopted in Conference substituted the "much narrower definition" provided under the FLSA. ${ }^{110}$ For Justice Ginsburg, this legislative history established that the agricultural laborer exemption was targeted to the family-size farm rather than to industrial-scale agribusiness operations. In addition, the legislative history supported the Act's overall purpose of offering basic protections to private sector employees by avoiding unduly expansive interpretations of a statutory exemption. ${ }^{111}$

Justice Ginsburg then proceeded to explain at some length why the Board's position - that these live-haul activities undertaken as part of chicken-processing were not "incident to or in conjunction with ... farming operations"112 - was a reasonable construction of the statute even if it might not be the best interpretation. ${ }^{113}$ She considered the employer's arguments plausible in several respects, but she placed considerable weight on the agency's longstanding consistent approach to vertically integrated poultry production. ${ }^{114}$ In the end, the Board's factual determinations had sufficient basis in the record, and its textual interpretations were sufficiently defensible, to qualify as reasonable and hence deserving of affirmance. ${ }^{115}$ Justice Ginsburg's analysis was disputed by the four dissenting Justices, for whom the FLSA definition unambiguously established that most of the employees in this instance were performing agricultural work. ${ }^{116}$ The dissent saw no basis for relying on either legislative history or agency deference given the clarity of controlling text. ${ }^{117}$

Although the poultry-processing industry was not happy with the Court's ruling, ${ }^{118}$ Holly Farms has generated little discussion. ${ }^{119}$ Members of

109 See id. at 399 n.6.

110 See id. (internal citation omitted); see also id. at $402 \mathrm{n} .8$ (discussing legislative history accompanying the language of FLSA definition).

111 See id. at 399 \& n.6.

112 See id. at 398 (quoting from FLSA definition of "agriculture").

113 See Holly Farms, 517 U.S. at 399-408.

114 See id. at 401-05.

115 See id. at $404-09$.

116 See id. at 410, 413-15 (O'Connor, J., dissenting, joined by Rehnquist, C.J., Scalia and Thomas, JJ.).

117 See id. at 411-12.

118 See, e.g., James Rosen, Supreme Court Backs N.C. Chicken Catchers, RALEIGH NEws \& OBSERVER, Apr. 24, 1996, at 3A (reporting reaction of Tyson Foods, Inc.); Lyle Denniston, Poultry Workers Have Union Rights, High Court Says, BALT. SUN, Apr. 24, 1996, at 2C (reporting reaction of National Broiler Council). 
Congress offered no critical response, much less any initiative to seek an override. ${ }^{120}$ The muted reaction may well reflect that unlike Health Care, the decision in Holly Farms is of limited practical import. The Court's opinion applies to a small number of farm-related workers involved in food processing, but the vast majority of agricultural laborers remain exempt from coverage under the NLRA. ${ }^{121}$

The Court's decision in Olmstead v. L.C. ex rel. Zimring ${ }^{122}$ construes a different federal statute, the Americans with Disabilities Act (ADA). ${ }^{123}$ The question that arose under Title II of the ADA, addressed to public services, was whether the ADA's proscription on discrimination might in certain circumstances require that individuals with mental disabilities be shifted from institutional care to a community-based setting. ${ }^{124}$ The Court's answer was Yes. Writing for a five-member majority, Justice Ginsburg held that Congress and the Executive had endorsed a broad meaning for discrimination, aimed at encouraging integration of individuals with disabilities into community-based settings. ${ }^{125}$

In Olmstead, two women with mental retardation and histories of mental illness had been institutionalized for prolonged periods after their treating psychiatrists concluded their needs could be appropriately met in community-based programs. ${ }^{126}$ The women claimed their unnecessary institutionalization amounted to unlawful discrimination under Title II of the

119 A handful of legal observers found the majority's position persuasive. See, e.g., Bernard Schwartz, Administrative Law Cases During 1996, 49 ADMIN. L. REV. 519, 542 (1997); Victoria V. Johnson, Did Old MacDonald Have a Farm? Holly Farms Corp. v. National Labor Relations Board, 69 U. CoLO. L. REV. 295 (1998).

${ }^{120}$ Melanie Oberlin, Library Reference Specialist at the Moritz College of Law, searched Westlaw's Congressional Bills database (CONG-BILL-TXT-ALL) and Congressional Record database (CR) on October 22, 2008. Two searches were run in each database: "holly farms"; poultry AND laborer AND "national labor relations." The searches yielded no relevant results.

${ }^{121}$ See Michael H. LeRoy \& Wallace Hendricks, Should "Agricultural Laborers" Continue to Be Excluded From the National Labor Relations Act?, 48 Emory L.J. 489, 494, 507-12 (1999) (arguing that Supreme Court decisions narrowing scope of agricultural laborer exemption have had minimal impact).

122527 U.S. 581 (1999).

123 Americans with Disabilities Act of 1990, Pub. L. No. 101-336, 104 Stat. 327 (codified at 42 U.S.C. $\S \S 12101-12213$ (2006)).

124 See Olmstead, 527 U.S. at 587 (1999).

125 See id. at 589-92, 597-603. Justice Ginsburg also discusses the appropriate remedy in less broad terms. See infra notes 134-35 and accompanying text.

126 See Olmstead, 527 U.S. at 593-94. 
ADA. ${ }^{127}$ The State of Georgia responded that because it did not provide community placement to those without disabilities, the exclusion from community placement of individuals with disabilities could not qualify as discrimination "by reason of" disability under the statute. ${ }^{128}$ Justice Ginsburg rejected the State's argument, because she was "satisfied that Congress had a more comprehensive view of the concept of discrimination" under the ADA. ${ }^{129}$

Ginsburg relied initially on two background provisions of the ADA to reveal Congress's more comprehensive approach to discrimination. The ADA statement of findings described society's tendency to isolate and segregate individuals with disabilities, and it identified segregation through institutionalized settings as a form of discrimination. 130 The statute's provision for regulations directed the Attorney General to promulgate rules implementing Title II, and it specified that these rules must be consistent with regulations from an earlier federal law mandating that programs and activities be administered "in the most integrated setting appropriate to the needs of" individuals with disabilities. ${ }^{131}$ Ginsburg noted that the Attorney General's Title II regulations had followed through in this respect, requiring state entities to support settings that allow individuals with disabilities to interact "to the fullest extent possible" with non-disabled persons, while also specifying that states not be required to make modifications that would "fundamentally alter the nature of the service, program, or activity" they provide. ${ }^{132}$

For Justice Ginsburg and her majority, these key legislative and regulatory provisions grounded the Court's conclusion that "unjustified institutional isolation" of individuals with disabilities does qualify as a form of discrimination-both because it perpetuates stereotypes about the capabilities of institutionally confined individuals and because it diminishes the everyday life activities of those individuals. ${ }^{133}$ At the same time-and

127 See id. at 594.

128 See id. Justice Thomas in dissent, joined by Chief Justice Rehnquist and Justice Scalia, adopted this position as well. See id. at 615-20 (Thomas, J. dissenting).

${ }^{129}$ Id. at 598 (majority opinion) (emphasis added).

${ }^{130}$ See id. at 588-89 (quoting 42 U.S.C. $\$ 12101(a)$ ).

131 See Olmstead, 527 U.S. at 591-92 (quoting and amplifying 28 C.F.R. $\S 41.51(\mathrm{~d}))$.

$132 \mathrm{See}$ id. at 592 (quoting 28 C.F.R. pt. 35, App. A, and 28 C.F.R. $\S 35.130(b)(7)(1998)$ (emphasis added)).

133 See id. at 599-601. 
writing here only for a plurality 134 -Ginsburg concluded that the "fundamental alteration" component of the regulations allows states considerable leeway in determining when and how to implement deinstitutionalization. In particular, a state may consider the impact of less restrictive confinements not only on its mental health budget but also on its responsibility for serving a diverse mental health population. ${ }^{135}$

Olmstead has been hailed as a landmark decision, with Justice Ginsburg's endorsement of the integrationist approach compared favorably to the Court's decision in Brown v. Board of Education. ${ }^{136}$ At the same time, disability rights scholars have expressed concerns both that deinstitutionalization could be unduly delayed by the discretion given to states to resist "fundamental alteration"137 and that overly zealous integration policies could deprive more seriously disabled individuals of needed assistance. ${ }^{138}$

Apart from its implications for disability law, the Olmstead opinion is an especially clear example of deference to the political branches. Justice Ginsburg structures her reasoning from the start by establishing how congressional findings and regulatory formulations inform the expansive meaning of "discrimination" adopted" by the majority. ${ }^{139}$ Similarly, the deference to the judgment of state actors embraced by the plurality stems directly from Ginsburg's respect for the Justice Department regulations and also the Department's position as amicus before the Court. ${ }^{140}$

134 See id. at 603-06; Justice Stevens did not join this part of Justice Ginsburg's opinion, although Justices Breyer, O'Connor, and Souter did.

135 See id. at 594-95, 604.

136 See, e.g., Samuel R. Bagenstos, Justice Ginsburg and the Judicial Role in Expanding "We The People": The Disability Rights Cases, 104 ColuM. L. REV. 49, 55 (2004); Mary C. Cerreto, Olmstead: The Brown v. Board of Education for Disability Rights, 3 LOY. J. PUB. INT. L. 47 (2001); Jefferson D. E. Smith \& Steve P. Calandrillo, Forward to Fundamental Alteration: Addressing ADA Title II Integration Lawsuits After Olmstead v. L.C., 24 HARV. J.L. \& PUB. POL'Y 695, 698 (2001).

137 See, e.g., Andrew I. Batavia, A Right to Personal Assistance Services: "Most Integrated Setting Appropriate" Requirements and the Independent Living Model of Long-Term Care, 27 AM. J.L. \& MED. 17, 35 (2001); The Supreme Court: Leading Cases, 113 HARV. L. REV. 326, 326-27, 332-36 (1999).

138 See, e.g., Carlos Ball, Looking for Theory in All the Right Places: Feminist and Communitarian Elements of Disability Discrimination Law, 66 OHIO ST. L.J. 105, 16164 (2005); Ruth Colker, Anti-Subordination Above All: A Disability Perspective, 82 Notre DAME L. REV. 1415, 1445-48 (2007); see also Olmstead, 527 U.S. at 608-10 (Kennedy, J., concurring) (expressing similar concerns about excessive zeal in deinstitutionalizing mental patients).

139 See 527 U.S. at 588-93 (Part I of Ginsburg opinion).

140 See id. at 603-06 (Part II B of Ginsburg opinion). 
Moreover, Justice Ginsburg when writing for a plurality recognizes the considerable burdens and costs that might be borne by an additional set of politically accountable actors-the States. ${ }^{141}$ Her opinion effectively invites state psychiatrists treating persons with mental disabilities, and state legislatures funding the range of treatment options, to take the initiative in making the Court's integrationist approach workable. ${ }^{142}$

There are indications that both the federal executive and the states have made measured progress in implementing the requirements of Olmstead. ${ }^{143}$ Whether this progress has been too slow is a subject of continuing review among mental health professionals as well as lower federal courts. ${ }^{144}$ Congress, though, seems reasonably content with the Court's decision. In the recently enacted ADA Amendments of 2008, Congress overrode as many as four Supreme Court decisions construing the Act, but offered no criticism of Olmstead. ${ }^{145}$

As with the four Ginsburg opinions in criminal law, the labor and civil rights opinions discussed in this Part are not offered as empirically

141 See id. at 603 (expressing concern that States not be left "virtually defenseless" with respect to their mental health budgets); id. at 605 (emphasizing States' need to balance services for mentally disabled population that requires institutional care with services for individuals ready for less restrictive settings).

142 See id. at 604-06; Bagenstos, supra note 136, at 58-59.

143 For Federal Executive Branch progress, see, e.g., Exec. Order No. 13,217, 3 C.F.R. 774 (2001 Compilation Parts 100-02), reprinted in 42 U.S.C. $§ 12131$ (Supp. IV 2005) (requiring inter alia that federal agencies provide coordinated technical assistance to states and identify specific federal barriers that impede community participation). For progress at state level, see generally Sara Rosenbaum \& Joel Teitelbaum, Olmstead at Five: Assessing the Impact, KAISER COMMISSION ON MEDICAID AND THE UNINSURED, June 2004, available at www.kff.org/Medicaid/7105a.cfm. For an excellent brief overview of Olmstead implementation issues, see Memorandum from John Billington to Ruth Colker (July 19, 2006) (copy on file with author).

144 See, e.g., Rosenbaum \& Teitelbaum, supra note 143, at 7-27; John V. Jacobi, Federal Power, Segregation, and Mental Disability, 39 Hous. L. REV. 1231, 1254 (2003). Compare Townsend v. Quasim, 328 F.3d 511 (9th Cir. 2003) (holding that state engaged in discriminatory administration), and Fisher v. Okla. Health Care Auth., 335 F.3d 1175 (10th Cir. 2003) (rejecting state's "fundamental alteration" defense) with Williams v. Wasserman, 164 F. Supp. 2d 591 (D. Md. 2001) (approving state's slower pace toward community integration).

145 The statute in its findings and purposes section rejects the holding and reasoning of two decisions: Sutton v. United Air Lines, Inc., 527 U.S. 471 (1999) and Toyota Motor Mfg., Ky., Inc. v. Williams, 534 U.S. 184 (2002). See Pub. L. No. 110-325, § 2, 122 Stat. 3553, 3553-54 (2008). The accompanying legislative history identifies four decisions that the statute was meant to override. See H.R. REP. No. 110-730, part 2, at 8, 10, 20 (2008) (discussing overrides of Sutton; Murphy v. UPS, 527 U.S. 516 (1999); Albertson's v. Kirkingburg, 527 U.S. 555 (1999); and Toyota Motor); 154 CONG. REC. S7956-57 (daily ed. July 31,2008 ) (statement of Sen. Harkin) (same). 
representative samples. Justice Ginsburg has authored workplace law or civil rights opinions that rely primarily on close textual readings and decline to seek interpretive guidance from legislative or Executive Branch commentary. ${ }^{146}$ At the same time, she has written additional civil rights opinions that in methodological terms resemble the trio of cases summarized above. ${ }^{147}$ And her attentiveness to legislative history, congressional purpose, and agency pronouncements is visible in other comprehensive civil regulatory settings as well. 148

Justice Ginsburg's reliance on contextual resources generated by the political branches stands in marked contrast to her interpretive stance in the four criminal law cases discussed in Part I. She seems far less comfortable with a close textual reading, and she eschews reliance on substantive canons, a reliance that was central when she construed federal criminal statutes. One could argue that Ginsburg's choice of interpretive resources in both areas is primarily a function of her preferred outcomes. On this account, her use of textual analysis and substantive canons could be viewed as enabling the Court to deflect a conservative Congress on criminal cases, while her use of legislative history and agency deference allows the Court to support a liberal Congress on labor and civil rights decisions. ${ }^{149} \mathrm{But}$ as noted earlier, this ideological account is at best incomplete. In the criminal law decisions, Justice Ginsburg's support for white collar as well as street crime defendants does not align her with traditionally liberal Justices. ${ }^{150}$ Additionally, her opinion construing the ADA is more cautious than some disability rights advocates would have wanted. ${ }^{151}$

It seems likely that institutional factors have helped shape Ginsburg's interpretive approach at least as much as traditionally ideological considerations. Her close attention to legislative history and agency guidance in the areas of labor relations and civil rights reflects her view that the courts have a distinctly more respectful role to play when construing complex regulatory schemes like the NLRA or the ADA. Rather than pushing

146 See Clackamas Gastroenterology Assocs. v. Wells, 538 U.S. 440, 451-54 (2003) (dissenting opinion); Porter v. Nussle, 534 U.S. 516 (2002) (majority opinion).

147 See Ledbetter v. Goodyear Tire \& Rubber Co., 550 U.S. 618, 643-61 (2007) (dissenting opinion); Gisbrecht v. Barnhart, 535 U.S. 789 (2002).

148 See, e.g., Alaska Dep't of Envtl. Conservation v. EPA, 540 U.S. 461 (2004) (environmental law); United States v. O'Hagan, 521 U.S. 642 (1997) (securities law); Bank One Chi., N.A. v. Midwest Bank \& Trust Co., 516 U.S. 264 (1996) (banking law).

${ }^{149}$ See, e.g., supra text accompanying note 78, 92-98.

${ }^{150}$ See supra note 81 (discussing Ginsburg opinions in Ratzlaf and Muscarello); see also supra note 80 , and accompanying text (discussing how Ginsburg opinions reviewed here differ from broader Court trends).

151 See supra text accompanying note 137. 
Congress to clarify its policy preferences, Justice Ginsburg examines legislative history in an effort to understand those policy preferences, to apply in spirit as well as letter the legislative bargain or "deal" that was struck. Similarly, rather than being suspicious of Executive Branch initiatives, Ginsburg presumptively regards agency regulatory efforts as attempts to implement or even update Congress's legislative judgments.

One way to understand and perhaps explain Justice Ginsburg's two quite divergent methodological perspectives is by exploring institutional considerations in more depth, specifically the Court's shifting role as an interstitial actor.

\section{THE Judicial VoICE AND INSTITUTIONAL DIALOGUE}

\section{A. The Court's Interdependent Interpretive Role}

As a starting point, Justice Ginsburg's scholarly reflections on the role of the judiciary shed some light on her eclectic approach to statutory interpretation. While serving on the D.C. Circuit, Ginsburg delivered the Madison Lecture at NYU Law School. ${ }^{152}$ Her remarks focused on the potential for judicial missteps in constitutional decision-making, but they also resonate with respect to the judicial function when construing statutes.

Judge Ginsburg was mindful that the judicial role in shaping legal doctrine is an interdependent one:153 she emphasized that in order to be effective, judges should "engag[e] in a dialogue with, not a diatribe against, co-equal departments of government...."154 Ginsburg recognized that the Court must at times "step ahead of the political branches in pursuit of a constitutional precept," 155 and more broadly that many judicial interpretations are aptly characterized as a form of legislating. ${ }^{156}$ But she cautioned courts to engage in such legislating only on an interstitial basis, through "[m]easured motions" and again as part of a "dialogue with other organs of government ...."157

Six years earlier, in her Roth Lecture at University of Southern California Law School, Judge Ginsburg addressed the costs of legislative missteps, voicing concern that Congress was effectively requiring the federal (1992).

152 Ruth Bader Ginsburg, Speaking in a Judicial Voice, 67 N.Y.U. L. REV. 1185

153 See id. at 1198.

154 Id. at 1186.

155 See id. at 1206 (citing with approval Brown v. Board of Education).

156 See id. at 1198.

157 Id. 
courts to engage in too much legislating. ${ }^{158} \mathrm{Her}$ plea was for Congress to draft more carefully and to review and revise its statutory work product so that courts did not have to struggle regularly to create consistency or fill gaps. ${ }^{159}$ Borrowing from Judge Friendly's proposal in an earlier era, Ginsburg suggested that Congress create an internal "second look" mechanism for clarifying certain ambiguities or omissions as soon as courts identify them. ${ }^{160}$ She added that such statutory repairs could often be undertaken at no political cost, as many drafting defects lack partisan implications. ${ }^{161}$

The Ginsburg-Friendly proposal for a structure of corrective lawmaking involves two implicit assumptions that are at least debatable. The first is that Congress and the courts do-or should - value equally the goal of achieving clarity in statutory text. ${ }^{162}$ The second is that statutory corrections can be secured on a systemic basis without imposing considerable opportunity costs on Congress. ${ }^{163}$ Even assuming, however, that Congress were interested in legislating some clarifications following lower court decisions, and that such clarifications could be achieved at little partisan or institutional cost, it is far from clear that clarifications responding to Supreme Court decisions would fall routinely into this category. The prospect of political salience-if not controversy - is surely present with respect to these decisions, as they often trigger high-profile partisan and ideological differences among members of Congress.

In addition, as Judge Friendly recognized, there may be good reason for Congress to frame some statutes in expansive, albeit ambiguous terms. (1986).

158 Ruth Bader Ginsburg, A Plea for Legislative Review, 60 S. CAL. L. REV. 995

159 See id. at $995-96,1000-01$.

160 See id. at 1011-17 (building on recommendations from Henry J. Friendly, The Gap in Lawmaking - Judges Who Can't and Legislators Who Won't, 63 COLUM. L. REV. 787 (1963)).

161 See Ginsburg, supra note 158, at 1013.

162 See Victoria F. Nourse \& Jane S. Schacter, The Politics of Legislative Drafting: A Congressional Case Study, 77 N.Y.U. L. REV. 575, 590-604 (2002) (describing view of legislators and their key staff that drafting text involves a contextualized and intensely pressured search for consensus, with canons and other rules that promote clarity and predictability playing a peripheral role); Breyer, supra note 2, at 870-71 (questioning whether legislators are aided by knowledge that court-produced canons may govern future legislation, especially given a less-than-efficient legislative process characterized by decentralized and partisan bargaining).

163 See James J. Brudney, Congressional Commentary on Judicial Interpretations of Statutes: Idle Chatter or Telling Response?, 93 MICH. L. REV. 1, $20-40$ (1994) (discussing institutional costs to Congress of having to clarify textual ambiguities, and the role of legislative history in helping to minimize those costs). 
Friendly referred with approval to federal labor laws having left courts and agencies "free to perform their historic role of formulating more definite standards within the general mandate."164 Legislative rules and definitions often seek to set forth complex regulatory ideas or concepts, such as the contours of an employer-employee relationship or what constitutes unlawful discrimination. Precisely because "words are treacherous for the transmission of [such] ideas," 165 rules and definitions that are too specific or exhaustive are likely to end up covering both more and less than their congressional authors sought to address. They also are likely-as Judge Friendly intimated - to constrain agencies, courts, and private parties in their ability to adjust to circumstances unforeseen or unforeseeable at time of enactment. ${ }^{166}$

Notwithstanding pragmatic concerns about the Ginsburg-Friendly approach, the two Ginsburg lectures reveal a firm belief that federal courts should strive to interact with the political branches as part of fulfilling their basic interpretive role. This role inevitably will include both creative judicial constructions and invitations to Congress to draft with greater clarity. But in undertaking such initiatives, Ginsburg counsels a healthy dose of humility: courts should make clear their interest in and commitment to an ongoing conversation with Congress and the Executive. Against this background, it is worth examining why Justice Ginsburg's dialogue with Congress develops differently in these two subject areas, why her judicial voice is more robust and proactive on matters of criminal law interpretation than on workplace law disputes.

\section{B. Institutional Comity and Congressional Overrides}

Conventional wisdom suggests that given its power to correct judicial mistakes, "[i]n the domain of statutory interpretation, Congress is the master."167 The growth of committee staffs, along with Congress's heightened mistrust of the other branches, has led to greater legislative scrutiny of federal court decisions. ${ }^{168}$ At the Supreme Court level, congressional overrides increased substantially in the years from 1974 to

164 Friendly, supra note 160 , at 792.

165 Douglas, supra note 1 , at 19.

166 See generally Brudney, supra note 163, at 29.

167 W. Va. Univ. Hosp. Inc. v. Casey, 499 U.S. 83, 115 (1991) (Stevens, J., dissenting).

168 See Jeb Barnes, Overruled? Legislative Overrides, Pluralism, and CONTEMPORARY COURT-CONGRESS RELATIONS 43 (2004). See generally Richard Paschal, The Continuing Colloquy: Congress and the Finality of the Supreme Court, 8 J.L. \& POL. 143, 199-203 (1991). 
$1990,{ }^{169}$ and there is no suggestion that Congress's attentiveness has diminished in the past two decades. 170

Overrides of the Court's criminal law decisions have been especially frequent since the 1960s. ${ }^{171}$ Political scientists and legal scholars identify several contributing factors in the criminal law area. The Court may be reluctant to sustain criminal convictions due to considerations of notice and fairness that raise constitutionally related policy concerns, yet the Court's concerns can be addressed by sufficiently clear statutory text. ${ }^{172}$ In addition, the fact that the Justice Department was the losing party before the Court means that members of Congress often have the Executive Branch as a powerful ally or even initiator of override proposals. ${ }^{173}$ Relatedly, the Court

${ }^{169}$ See William N. Eskridge, Jr., Overriding Supreme Court Statutory Interpretation Decisions, 101 YALE L.J. 331, 338 (1991) (reporting data indicating that Congress overrode 5.7 Court decisions on average for each Congress from 1967-1974, but 12.6 Court decisions per Congress from 1975-1990).

170 See, e.g., supra note 36 and note 77 and accompanying text (discussing 1994 and 1998 overrides of criminal law decisions); supra note 145 and accompanying text (discussing 2008 override of four civil rights decisions). See generally Lori Hausegger \& Lawrence Baum, Behind the Scenes: The Supreme Court and Congress in Statutory Interpretation, in GREAT THEATRE: THE AMERICAN CONGRESS IN THE 1990s 224, 228 (Herbert F. Weisberg \& Samuel C. Patterson eds., 1998) (discussing overrides through 1996).

171 See Eskridge, supra note 169, at 344-45 (reporting that $15 \%$ of congressional overrides from 1967-1990 involved criminal law, and the next highest subject matters addressed-antitrust and civil rights-were at only $9 \%$ while income tax was at $7 \%$ ); Nancy C. Staudt et al., Judicial Decisions as Legislation: Congressional Oversight of Supreme Court Tax Cases 1954-2005, 82 N.Y.U. L. REV. 1340, 1354 (2007) (reporting that of 279 Supreme Court tax decisions from 1954 to 2004, 8\% were overridden); see also EINER ElHAUge, STATUTORY DeFault RULES 358 (2008) (suggesting that Eskridge study actually understates frequency of Court's criminal law overrides). But cf. Ruth Colker, The Mythic 43 Million Americans with Disabilities, 49 WM. \& MARY L. REv. 1, $14 \mathrm{n.49}$ (2007) (suggesting that Eskridge study may overstate frequency of overrides generally during 1967-90 period).

172 See William N. Eskridge, Jr. \& Philip P. Frickey, Quasi-Constitutional Law: Clear Statement Rules as Constitutional Lawmaking, 45 VAND. L. REV. 593, 600 (discussing rule of lenity); Note, The Mercy of Scalia: Statutory Construction and the Rule of Lenity, 29 HARV. C.R.-C.L. L. REV. 197, 202-03 (same); cf. Eskridge, supra note 169 , at 389 (discussing Court's institutional signaling by use of constitutionally inspired clear statement rules). See generally Lori Hausegger \& Lawrence Baum, Inviting Congressional Action: A Study of Supreme Court Motivations in Statutory Interpretation, 43 AM. J. POL. SCI. 162 (1999).

173 See BARNES, supra note 168, at 163-64 (finding that Congress more likely to override if federal government has direct stake in reversing outcome); Hausegger \& Baum, supra note 170 , at $240-42$ (finding override more than twice as likely when United States was a party on losing side). Although these findings are tempered if the 
is more likely to issue invitations to Congress in subject areas such as criminal law where it expects overrides to be relatively frequent. ${ }^{174}$ This is at least partly a matter of institutional self-protection. When the Court concludes based on its faithful construction of the statute that a conviction must be reversed, the Justices may still want to minimize criticism from legislators-and also the public and the media-by in effect hedging their bets and shifting ultimate responsibility to Congress to fix the problem. ${ }^{175}$

Each of these factors is relevant when considering Justice Ginsburg's proactive approach to construing criminal statutes. In her trio of criminal law majorities, Ginsburg worries about the risk that individuals will be punished for conduct that lacked a criminal motive, ${ }^{176}$ or for actions they could not reasonably anticipate were prohibited by Congress, ${ }^{177}$ especially when such actions traditionally had been regulated only by the states and state governments are not parties to the disputes before the Court. ${ }^{178}$ These constitutionally grounded concerns involving notice, fairness, and federalism lead Ginsburg to impose on Congress the burden of issuing clearer directives, a burden she further justifies in her Muscarello dissent. ${ }^{179}$ At the same time, Justice Ginsburg understands from her initial Term on the Court, if not earlier, that Congress-assisted by the Justice Department-is quite prepared to assume this burden with respect to criminal statutes. Her suggestions that Congress should speak more clearly are made knowing that Congress has the will to act promptly and decisively on criminal law matters. When inviting Congress to respond, Justice Ginsburg opts for dialogue over diatribe. Reversing criminal convictions can make the Court unpopular with the

Court's opinion is unanimous, id. at 241 , the Court's strategic institutional concerns still tend to come into play.

174 See Hausegger \& Baum, supra note 172, at 167; see also ElHAUGE, supra note 171 , at 168-69 (contending that lenity-based narrowing interpretations of criminal statutes are especially likely to be corrected by overrides because prosecutors and other members of anti-criminal lobbying groups are regularly involved in drafting and have ready access to legislative agenda); Joseph Ignagni \& James Meernik, Explaining Congressional Attempts to Reverse Supreme Court Decisions, 47 POL. RES. Q. 353, 357 (1994) (contending that members feel encouraged to seek overrides of Court decisions on which there are public indications of displeasure).

175 See Hausegger \& Baum, supra note 172, at 172-73; see also ElHAUGE, supra note 171 , at 256 (relying on Hausegger \& Baum findings to contend that when Court concludes plain meaning requires reversal of conviction, it may also invite override to signal its possible or likely policy disagreement with conclusion reached).

176 See supra note 29 and accompanying text (discussing Ratzlaf).

177 See supra notes 42-48 and accompanying text (discussing Cleveland).

178 See supra notes 45-46 and 61-65 and accompanying text (discussing Cleveland and Jones).

${ }^{179}$ See supra note 75 and accompanying text (discussing Muscarello). 
public as well as the political branches. By signaling to Congress that it may have the last word, Ginsburg respects the legislature's institutional role while also diminishing prospects that the Court will suffer any lasting reputational damage. ${ }^{180}$

The institutional backdrop to Justice Ginsburg's two labor law opinions is rather different. Unlike Supreme Court criminal law cases, overrides of the Court's labor law decisions are virtually nonexistent. ${ }^{181}$ The contrast is part of a larger track record: Congress has been immobilized with respect to the NLRA for half a century. ${ }^{182}$ Given this prolonged period of interest group gridlock and legislative paralysis, the Court can operate without meaningful risk or threat of override. Indeed, if a majority opinion did invite Congress to speak more clearly on an NLRA interpretive issue, the Court might well be viewed as mocking Congress's inability to revisit the statute.

That the Court is able to operate more freely on NLRA matters absent the shadow of an override does not mean it ought to do so. The NLRA was enacted as a comprehensive regulatory scheme, aimed at significantly altering the pre-existing legal landscape of rights and duties. ${ }^{183}$ The 1935 Act

180 Professor Elhauge in his recent book suggests that the Rule of Lenity and other canons favoring the politically powerless are best understood as preference-eliciting default rules to address otherwise unresolved statutory ambiguity. See ELHAUGE, supra note 171 , at 151-81, 185-87. Elhauge, however, presents such canons as a third-best option, to be invoked as a tiebreaker only if there are no agency decisions from which to infer current enactable preferences and no legislative history allowing for estimation of enactor preferences. See id. at 9-12; Susan Phillips Read, Statutory Resolution, 12 GREEN BAG 2D 85, 86-89 (2008). Further, Elhauge regards the canon against preemption of state law as a supplemental default rule of even lower priority, to be invoked in support of federalism as a substantive value in cases where federally enactable preferences can be neither reliably estimated nor practically elicited. See ELHAUGE, supra at 229-32.

Justice Ginsburg is far more proactive and determined when invoking both the Rule of Lenity and the anti-preemption canon in a criminal setting. In her three majority opinions, Ginsburg concludes that the text is clear but she nonetheless makes use of the canons to amplify her holding from policy and strategic standpoints. In relying on the two canons, Ginsburg discounts contrary legislative history in her five-to-four majority and she develops them as additional justifications in her two unanimous majorities. Further, in Muscarello, her dissent takes direct issue with the notion of lenity as a tiebreaker, insisting that unless legislative history and Executive Branch construction establish the pro-prosecution statutory reading as unambiguously correct, courts are bound to rule for the criminal defendant.

181 See Eskridge, supra note 169, at 344.

182 See generally James J. Brudney, Isolated and Politicized: The NLRB's Uncertain Future, 26 COMP. LAB. L \& POL'Y J. 221, 228 (2005); Cynthia L. Estlund, The Ossification of American Labor Law, 102 COLUM. L. REV. 1527, 1535, 1540-43 (2002).

183 See generally IRVING BernsteIn, The New Deal Collective Bargaining POLICY 129-39 (1950); PETER H. IRONS, THE NEW DEAL LAWYERS 226-29 (1982); Leon 
and its 1947 and 1959 amendments also constitute a complex series of legislative bargains that the business community and organized labor were intimately involved in negotiating. ${ }^{184}$ As judges and scholars recognize with respect to regulatory schemes in general, the legislative history accompanying such bargains can be a valuable resource to help explain various details and specific applications. ${ }^{185}$ By the same token, if courts ignore or discount relevant legislative history, they may-even if inadvertently - be tampering with or undoing certain aspects of the deals that were made. The regulatory structure enacted pursuant to these deals will often have survived the erosion of political coalitions and popular intensity that initially produced them. But if Congress has not repealed, modified, or even specifically addressed the text framing the legislative bargains, then the proper interdependent role for courts may be to pay close attention to what Congress thought it was doing when it enacted the text in question. ${ }^{186}$

A further element of interstitial judicial activity in this setting is attentiveness to interpretations by the executive agency charged with implementing the regulatory scheme. An agency like the NLRB is not responsible for the larger legal landscape; its mission is fidelity to the Act that created it. The Board's specialized provenance and limited jurisdiction should tend to make it more loyal to the Act's original purposes and intent than many federal judges, for whom there may be pressure to readjust the

H. Keyserling, Why the Wagner Act?, in THE WAGNER ACT: AfTER TEN YEARS 5-18 (Louis G. Silverburg ed., 1945).

184 See generally BERNSTEIN, supra note 183 (discussing 1935 Act); Keyserling, supra note 183 (same); Archibald Cox, Some Aspects of the Labor Management Relations Act 1947, 61 HARV. L. REV. 1, 5-19 (1947) (discussing 1947 Act); Archibald Cox, The Landrum-Griffin Amendments to the National Labor Relations Act, 44 MINN. L. REV. 257, 258-60 (1959) (discussing 1959 Act).

185 See, e.g., Landgraf v. USI Film Prods., 511 U.S. 244, 250-63 (1994) (relying on legislative history to explain compromise over retroactivity provisions of 1991 Civil Rights Act); Jackson Transit Auth. v. Amalgamated Transit Union, 457 U.S. 15, 24-29 (1982) (relying on legislative history to explain retention of state labor law provisions in 1964 Urban Mass Transportation Act); Beasley v. Food Fair of N.C., 416 U.S. 653, 65962 (1974) (using legislative history to explain exemption of supervisors from state law coverage under NLRA). See generally Stephen Breyer, On the Uses of Legislative History in Interpreting Statutes, 65 S. CAL. L. REV. 845, 858-60 (1992); McNollgast, Positive Canons: The Role of Legislative Bargains in Statutory Interpretation, 80 GEO. L.J. 705, 724-27 (1992); James J. Brudney \& Corey Ditslear, Liberal Justices' Reliance on Legislative History: Principle, Strategy, and the Scalia Effect, 29 BERKELEY J. EMP. \& LAB. L. 117, 146-53, 157-60 (2008).

186 See James J. Brudney, A Famous Victory: Collective Bargaining Protections and the Statutory Aging Process, 74 N.C. L. REV. 939, 1030-34 (1996); William M. Landes \& Richard A. Posner, The Independent Judiciary in an Interest-Group Perspective, 18 J.L. \& ECON. 875, 877-79 (1975). 
original congressional priorities of an older statute like the NLRA in order to accommodate extrinsic changes in the regulated marketplace. ${ }^{187}$ The Board will at times be deemed to have construed the original purposes in an arbitrary manner or even to have acted in something akin to bad faith. ${ }^{188}$ But more often, especially when the Board's interpretation reinforces or comports with the relevant legislative history, the Court's most constructive role in dialogic terms may well be to follow the lead of the two other branches.

This inquisitive yet ultimately deferential stance toward contextual resources produced by Congress and the Executive is consistent with Justice Ginsburg's interpretive approach in her NLRA opinions. In both Health Care and Holly Farms, she places heavy reliance on legislative history and agency guidance. In neither case does Ginsburg hint at the possibility of inviting a congressional response to the Court's interpretation, even the majority's textualist opinion in Health Care from which she strongly dissents. ${ }^{189}$ To be sure, the federal government is on the losing side in Health Care as it was in Ratzlaf, Cleveland, and Jones. But the NLRB is not a serious legislative player the way the Justice Department is on criminal law matters. And Congress in the mid 1990s-especially a newly elected Republican Congress-is extremely unlikely to respond legislatively after failing to revisit the NLRA since 1959. In these circumstances, Ginsburg views the Court's role as being deferential rather than proactive toward the regulatory scheme Congress enacted decades earlier. Her majority as well as her dissent suggest that the Court's interdependence in this setting pushes toward its focusing on legislative history and agency guidance, not on judicially promulgated assets like ordinary meaning or the canons.

187 See, e.g., WILLIAM N. ESKRIDGE, JR., DYNAMIC STATUTORY INTERPRETATION 81-105 (1994) (describing how federal courts between 1877 and 1938 constructed the authority to impose labor injunctions from various extrinsic developments in federal law); William N. Eskridge, Jr., Dynamic Statutory Interpretation, 135 U. PA. L. REv. 1479, 1488-93, 1516 (1987) (describing how Supreme Court in Weber validated affirmative action by relying on "the legal culture's rethinking of the concept of discrimination" between 1964 and 1979); see also Brudney, supra note 186, at 1002-09, 1023-28 (discussing how appellate courts from 1986-1993 acted to restrict bargaining orders out of respect for individual employee rights); Terry A. Bethel \& Catherine A. Melfi, Judicial Enforcement of NLRB Bargaining Orders: What Influences the Courts?, 22 U.C. DAVIS L. REV. 139, 161-62, 173-75 (1988) (reporting similarly high nonenforcement rates for bargaining orders in 1970s and early 1980s).

${ }^{188}$ See generally Brudney, supra note 182 , at 221-22, 224-26 (discussing barrage of criticism for recent Board decisions weakening employees' rights to engage in organizing and collective bargaining under NLRA).

189 Justice Kennedy's majority opinion discounts legislative history and the agency's position as Ginsburg did in her criminal law trilogy, but he too eschews any whisper of an invitation to Congress to revisit the "supervisor" issue. 
The final Ginsburg opinion, involving the ADA, reveals a slightly different approach to her goal of recognizing institutional interdependence. Unlike the situation with the NLRA, Congress does revisit our national civil rights laws-notably Title VII and the ADEA - on a periodic basis. ${ }^{190}$ At the same time, congressional overrides of Supreme Court civil rights decisions are not as frequent or piecemeal as has occurred in the criminal law area. ${ }^{191}$ Apart from Olmstead, the Court in 1999 issued several other controversial decisions applying the ADA. ${ }^{192}$ Despite considerable criticism of those Court decisions and of the trend in lower court cases heavily disfavoring ADA plaintiffs, ${ }^{193}$ Congress did not revisit the ADA at all until 2008, eighteen years after its enactment. ${ }^{194}$

190 See, e.g., Equal Employment Opportunity Act of 1972, Pub. L. No. 92-261, 86 Stat. 103 (Title VII); Pregnancy Discrimination Act of 1978, Pub. L. No. 95-555, 92 Stat. 2076 (Title VII); Age Discrimination in Employment Act Amendments of 1978, Pub. L. No. 95-256, 92 Stat. 189 (ADEA); Age Discrimination in Employment Amendments of 1986, Pub. L. No. 99-592, 100 Stat. 3342 (ADEA); Older Workers Benefit Protection Act of 1990, Pub. L. No. 101-433, 104 Stat. 978 (ADEA); Civil Rights Act of 1991, Pub. L. No. 102-166, 105 Stat. 1071 (Title VII).

191 See Eskridge, supra note 169, at 344-45 (reporting that between 1967 and 1990, Congress overrode eighteen criminal law decisions and eleven civil rights decisions). Congress typically overrode single criminal law decisions in a statute during this period.; See, e.g., Crime Control Act of 1990, Pub. L. No. 101-647, § 3103, 104 Stat. 4789, 4916 (overriding Penn. Dept. of Pub. Welfare v. Davenport, 495 U.S. 552 (1990)); Anti-Drug Abuse Act of 1988, Pub. L. No. 100-690, § 7603, 102 Stat. 4181, 4508 (1988) (overriding McNally v. United States, 483 U.S. 350 (1987)); Prescription Drug Mktg. Act of 1987, Pub. L. No. 100-293, § 4, 102 Stat. 95, 96 (1988) (overriding United States v. Park, 421 U.S. 658 (1975)); Sexual Abuse Act of 1986, Pub. L. No. 99-654, § 2, 100 Stat. 3660, 3660-63 (1986) (overriding Williams v. United States, 327 U.S. 711 (1946)). By contrast, the 1991 Civil Rights Act and 2008 Americans with Disabilities Act amendments are instances of more systemic responses. See infra note 207; supra note 145 \& accompanying text. But see infra text accompanying notes 206 and 208 (discussing single-case overrides amending Title VII in 1978 Pregnancy Discrimination Act and 2009 Lilly Ledbetter Fair Pay Act, plus Congress's override response in 1987 Civil Rights Restoration Act).

192 See Sutton v. United Air Lines, 527 U.S. 471 (1999); Murphy v. UPS, 527 U.S. 516 (1999); Albertson's v. Kirkingburg, 527 U.S. 555 (1999).

193 See Bonnie Poitras Tucker, The Supreme Court's Definition of Disability Under the ADA: A Return to the Dark Ages, 52 ALA. L. REv. 321 (2000) (critical of Supreme Court decisions); Ruth Colker, The Americans With Disabilities Act: $A$ Windfall for Defendants, 34 HARV. C.R.-C.L. L. REV. 99, 107-110 (1999) (reporting and discussing trend in lower court decisions).

194 See Chai R. Feldblum, Kevin Barry, \& Emily A. Benfer, The ADA Amendments Act of 2008, 13 TEX. J. C.L. \& C.R. 187, 195-99 (2008). Congressional action on civil rights has been less frequent since the early 1990 s, because Republicans controlled one or both chambers between 1994 and 2006. 
More broadly, the presence or absence of partisan divisions is a key difference between override potential in civil rights and criminal law. Congress is prepared to override criminal law decisions on an overwhelmingly bipartisan basis and without undue debate or delay. ${ }^{195} \mathrm{By}$ contrast, Congress's overrides of civil rights decisions are often closely contested and typically take considerably longer to accomplish. ${ }^{196}$

When Ginsburg wrote her Olmstead majority, she had no reason to anticipate a congressional capacity to override in the near future. In this setting, Ginsburg's opinion adopted an expansively purposive view of the ADA's key concept-discrimination. Her interpretation of the broadly remedial provision was informed by how she believed Congress and the Justice Department meant for it to apply to a population for whom segregation was a strong, continuing reality. Although Ginsburg could have adhered to the more formalistic and literal meaning of discrimination

195 See, e.g., Anti-Drug Abuse Act of 1988 (overriding McNally) (introduced in House Aug. 11, 1988; passed House 375-30 and Senate 87-3; signed by President Nov. 18, 1988), Library of Congress, THOMAS, Search Bill Summary \& Status for 100th Congress, H.R. 5210, http://thomas.loc.gov/bss/100search.html (search "H.R. 5210," then click on "Major Congressional Actions") (last visited Mar. 4, 2009); Riegle Community Development and Regulatory Improvement Act of 1994 (overriding Ratzlaf) (introduced in House Nov. 9, 1993 and approved by Voice Vote twelve days later; discharged from Senate Banking Committee by unanimous consent on Mar. 17, 1994, and passed Senate by unanimous consent on same day), Library of Congress, THOMAS, Search Bill Summary \& Status for 103d Congress, H.R. 3474, http://thomas.loc.gov/bss/ 103search.html (search "H.R. 3474," then click on "Major Congressional Actions") (last visited Mar. 4, 2009).

196 See, e.g., Civil Rights Restoration Act of 1987 (overriding Grove City) (introduced Feb. 1987; enacted over President Reagan's veto in Mar. 1988), Library of Congress, THOMAS, Search Bill Summary \& Status for the 100th Congress, S. 557, http://thomas.loc.gov/bss/100search.html (search "S. 557") (last visited Mar. 23, 2009); Older Workers Benefit Protection Act of 1990 (overriding Betts) (introduced Aug. 1989; enacted October 1990 following bipartisan Senate Floor compromise and withdrawal of President Bush's opposition), Library of Congress, THOMAS, Search Bill Summary \& Status for the 101st Congress, S. 1511, http://thomas.loc.gov/bss/101 search.html (search "older workers benefit protection," then click on "S. 1511") (last visited Mar. 23, 2009); Civil Rights Act of 1991 (overriding nine Supreme Court decisions) (introduced in Feb. 1990; approved by Congress but vetoed by President Bush in October 1990, veto sustained in Senate 66-34; re-introduced following extensive compromise negotiations in Sept. 1991 and became law in Nov. 1991), Library of Congress, THOMAS, Search Bill Summary \& Status for the 102d Congress, S. 1745, http://thomas.loc.gov/bss/102search.html (search "S. 1745") (last visited Mar. 23, 2009) and Library of Congress, THOMAS, Search Bill Summary \& Status for the 101st Congress, S. 2104, http://thomas.loc.gov/bss/101 search.html (search "Civil Rights Act," then click on "S. 2104") (last visited Mar. 23, 2009). 
advocated by the dissent, ${ }^{197}$ such an approach would have been-for her-an assertion of judicial independence rather than interdependence.

At the same time, Ginsburg in Olmstead did not go as far as she could have, or as some disability rights advocates may have wished she had. ${ }^{198} \mathrm{Her}$ hesitation was tied directly to her view that decisions about the speed and scope of deinstitutionalization carried complex and unforeseeable consequences, and the Court needed to give state governments ample discretion to plan for those consequences. ${ }^{199}$ Once again, Justice Ginsburg's tempered approach reflects a sensitivity to the Court's interstitial role, including its need to be respectful of the political process even as the Court directed that new steps be taken by key political actors.

\section{Theoretical Coherence and Practical Complexity}

There is one further notable connection between Justice Ginsburg's eclectic approach to statutory interpretation and her sensitivity to the vicissitudes of the legislative process. Recent empirical studies report that the Court's reliance on textualist assets such as ordinary meaning analysis and the canons is more likely to trigger overrides than its reliance on intentionalist assets such as legislative history or purpose. ${ }^{200}$ The finding that

197 See Olmstead, 527 U.S. 581, 615-18 (Thomas, J., dissenting) (arguing that term "discrimination" does not encompass disparate treatment among members of same protected class, but only applies to differential treatment between individuals inside versus outside protected class).

198 See, e.g., Leading Cases, supra note 137, at 326-27, 332-36 (criticizing Ginsburg's opinion for undue deference to state psychiatrists); Batavia, supra note 137, at 35 (expressing concern over possible delay in deinstitutionalization due to discretion vested in states).

199 See Olmstead, 527 U.S. at 603-06. See generally Michael L. Perlin, "Their Promises of Paradise": Will Olmstead v. L.C. Resuscitate the Constitutional "Least Restrictive Alternative" Principle in Mental Disability Law?, 37 Hous. L. REV. 999, 1036-37 (2000); Comment, Olmstead v. L.C.-Deinstitutionalization and Community Integration: An Awakening of the Nation's Conscience?, 58 MERCER L. REV. 1381, 1398-99 (2007).

200 See Eskridge, supra note 169 , at $347-48$ (reporting that nearly half the overrides from 1967 to 1990 address decisions in which the Court's primary reasoning was based on plain meaning or canons of construction, whereas overrides of decisions based on statutory purpose are rare); Michael E. Solimine \& James L. Walker, The Next Word: Congressional Response to Supreme Court Statutory Decisions, 65 TEMP. L. REV. 425, 448 (1992) (reporting that a disproportionate number of decisions between 1968 and 1988 that were overridden by Congress relied on a plain meaning analysis); see also Daniel J. Bussel, Textualism's Failures: A Study of Overruled Bankruptcy Decisions, 53 VAND. L. REV. 887, 900-910 (2000) (reporting that a disproportionate number of federal court decisions interpreting bankruptcy statute from 1979 to 1998 that were overridden 
a high proportion of these overrides now occur within a short period following the Court's decision ${ }^{201}$ lends some credence to the argument that the Court's textualist and canon-centered approach may be disguising an effort to undermine rather than respect the will of Congress. ${ }^{202}$

The Ginsburg opinions reviewed in this Article suggest that the picture is more complicated. Speaking for some liberal and some conservative members of the Court, ${ }^{203}$ Ginsburg invokes judicially generated resourcesthe canons and plain meaning analysis--when construing criminal statutes; in doing so she invites further deliberation and perhaps ultimately rejection from Congress. By contrast, speaking for a group of mostly liberal Justices, ${ }^{204}$ Ginsburg goes beyond textualism and relies on intentionalist resources-legislative history and agency deference-when construing labor and civil rights statutes that are less likely candidates for congressional override.

Unlike some of her colleagues on the Court, Justice Ginsburg's interpretive stance does not reflect a unified doctrinal approach to the use of interpretive resources. ${ }^{205}$ Instead, she seems determined to cast the Court's role in institutional terms, as an interpreter that engages in varying ways with

by Congress relied on textualist method). See generally FrANK B. CROSS, THE THEORY AND PRACTICE OF STATUTORY INTERPRETATION 82 (2009) (summarizing findings from various studies).

201 See Eskridge, supra note 169, at 450-55 (reporting that $62 \%$ of overrides between 1987 and 1990 occurred within two years of Court's decision, whereas $44 \%$ of overrides between 1982 and 1986, and 32\% of overrides between 1967 and 1981, were within two years of Court's decision).

${ }^{202}$ See, e.g., Stephen F. Ross, Where Have You Gone Karl Llewellyn? Should Congress Turn Its Lonely Eyes to You?, 45 VAND. L. REV. 561, 562 (1992); Steven R. Greenberger, Civil Rights and the Politics of Interpretation, 62 U. CoLO. L. REV. 37 (1991); Abner J. Mikva \& Jeff Bleich, When Congress Overrides the Court, 79 CAL. L. REv. 729 (1991); see also Brudney, supra note 163, at $47 \mathrm{n} .188$ (observing that a number of congressional overrides in late 1970 s and 1980 s occurred promptly enough to allow for ongoing participation by key members of Congress).

${ }^{203}$ See supra note 81 (discussing mixed liberal and conservative support for Ginsburg's opinions in two 5-4 criminal law decisions, and support from all liberals and conservatives for Ginsburg's two unanimous opinions).

${ }^{204}$ In the Holly Farms and Olmstead majorities, Ginsburg's opinions are joined by Justices Breyer, Souter, and Stevens. She also was joined by Justice O'Connor in Olmstead and by Justice Kennedy in Holly Farms. The Ginsburg dissent in Health Care was joined by Justices Stevens, Souter, and Blackmun.

205 See SCALIA, supra note 2 (advocating textualism); STEPHEN BREYER, ACTIVE LIBERTY 85-101 (2005) (advocating pragmatism); W. Va. Univ. Hosp., Inc. v. Casey, 499 U.S. 83, 112-16 (1991) (Stevens, J., dissenting) (advocating intentionalism); Bank One Chi. N.A. v. Midwest Bank \& Trust Co., 516 U.S. 264, 276-78 (1996) (Stevens, J., concurring) (same). 
the two other branches. In Ginsburg's view, the Court should be more activist in promoting clarity and predictability-even at the risk of frustrating Congress's likely purpose-when such clarity is important for constitutionally informed policy reasons and also is deemed relatively easy for Congress to achieve. On the other hand, the Court should be less willing to insist on clarity and predictability - and more committed to searching for and deferring to legislative intent-when the policy issues were resolved through complex regulatory bargains negotiated by experienced political actors on both sides. The Ginsburg approach may not be captured in a pristine interpretive theory, but it does offer the outline for a coherent interpretive framework.

At the same time, the approach ascribed to Justice Ginsburg has certain rough edges, perhaps too readily smoothed over in this Article. Legislative bargains negotiated by sophisticated players in the civil rights area are not always so resistant to congressional updating. The Court's Title VII cases may be less amenable to override than its criminal law decisions, but the Justices' interpretations of Title VII draw regular congressional interest, and these interpretations have led to overrides on a piecemeal ${ }^{206}$ as well as a systemic ${ }^{207}$ basis. Indeed, Congress in recent months overrode the Court's Ledbetter decision and in doing so responded to an impassioned Ginsburg dissent inviting just such action. ${ }^{208}$ Congress has shown a willingness to override the Court on individual ADEA decisions as well. ${ }^{209}$

It may be that over time, the ADA will come to resemble other major civil rights statutes such as Title VII and the ADEA more than the NLRA in terms of Congress's capacity to correct or override Supreme Court decisions with which it disagrees. Stepping back, Congress seems inclined to initiate

206 See 1987 Civil Rights Restoration Act, Pub. L. No. 100-259, 102 Stat. 28 (1988) (codified at 20 U.S.C. $\$ 1687$ ) (overriding Grove City Coll. v. Bell, 465 U.S. 555 (1984)); Pregnancy Discrimination Act of 1978, Pub. L. No. 95-555, 92 Stat. 2076 (codified at 42 U.S.C. $\S 2000 \mathrm{e}(\mathrm{k})$ ) (overriding Gen. Elec. Co. v. Gilbert, 429 U.S. 125 (1976)).

207 See Civil Rights Act of 1991, Pub. L. No. 102-166, 105 Stat. 1071 (overriding nine Supreme Court decisions issued from 1988 to 1990).

208 See Lilly Ledbetter Fair Pay Act of 2009, Pub L. No. 111-2, 123 Stat. 5 (2009); Ledbetter v. Goodyear Tire \& Rubber Co., 550 U.S. 618, 643 (2007) (Ginsburg, J., dissenting). It is not clear if Ginsburg anticipated Congress would act to override during the George W. Bush presidency or only when the White House was occupied by a Democrat. Either way, she evidently viewed the prospect of an override as far more likely with respect to this civil rights statute than under the NLRA.

209 See Older Workers Benefit Protection Act, Pub. L. No. 101-433, 104 Stat. 978 (1990) (overriding Pub. Employees Ret. Sys. v. Betts, 492 U.S. 158 (1989)); Age Discrimination in Employment Act Amendments of 1978, Pub. L. No. 95-256, 92 Stat. 189 (overriding United Airlines v. McMann, 434 U.S. 192 (1977)). 
override efforts in civil rights law more regularly than it does in labor relations (although less regularly than it does in criminal law). The difference between civil rights and labor relations reflects a stronger and more continuous public interest in civil rights issues as well as a more favorable political dynamic for interest groups promoting civil rights reforms. ${ }^{210}$ The Ginsburg interpretive framework may therefore point toward a continuum rather than a set of bright line distinctions. It is hard to argue that Justice Ginsburg would embrace such an adjustment, as this Article sets forth a framework she herself has not proposed. But the possibility of amplifying her approach may lead to a more open dialogue between the Justice and the legal academy regarding how best to set forth a coherent interpretive theory based on the institutional considerations she clearly values.

\section{CONCLUSION}

Justice Ginsburg's bottom line in the statutory decisions I have analyzed can fairly be characterized as liberal. This Article has argued, however, that Ginsburg's interpretive reasoning is in fact more nuanced and complex in engaging a distinct set of non-doctrinal considerations. Although the Justice has not articulated a second-order theory to explain differences in her interpretive approach, certain patterns do emerge. The seven opinions discussed here suggest that Ginsburg believes the Court should approach statutory cases with an eye toward fostering institutional dialogue and interbranch sensitivity, values the Justice has identified as important in her nonjudicial writings.

Judicial reasoning that attends to considerations of institutional comity is not without risks. Heightened sensitivity to the prospects for future congressional override may subject the Court to criticism that it has acted with insufficient regard for what the enacting Congress meant to accomplish. $^{211}$ At the same time, a cramped interpretation of prior

210 See JeFFrey M. BERRY, ThE NEW Liberalism 2-3, 70-71, 121 (1999) (discussing rising political influence of civil rights organizations as well as other liberal "citizen groups" since 1960 s, and shift in agenda of U.S. politics away from traditionally material issues); STEVEN GReEnhouse, THE BIG SQuEEZE: TOUGH TIMES for THE AMERICAN WORKER 241-45 (2008) (discussing decline of labor unions since 1950s in terms of power, prestige, and public consciousness); Brudney, supra note 182, at 227-29 (contrasting Congress's inability to enact labor law reform with its continuing interest in updating civil rights statutes).

211 See, e.g., ESKRIDGE ET AL., supra note 27, at 83-87 (arguing that Court acted strategically in setting civil rights policy in 1970s); Daniel B. Rodriguez \& Barry R. Weingast, The Positive Political Theory of Legislative History: New Perspectives on the 1964 Civil Rights Act and Its Interpretation, 151 U. PA. L. REV. 1417, 1428-29, 1499- 
congressional override text may create lingering "shadow precedents" that unduly confine what the correcting Congress intended to address. ${ }^{212}$

Justice Ginsburg's institutional approach arguably strives to minimize these two risks. By inviting Congress to respond to her text-and-canoncentered criminal law opinions, she maintains a respectful dialogue in anticipation of possible overrides. By invoking legislative history and Executive Branch guidance in her labor and civil rights opinions, she expresses a supportive and deferential position toward the political branches. ${ }^{213}$ Although Justice Ginsburg speaks less explicitly and at a lower decibel level on matters of statutory interpretation than some of her colleagues, her eclectic orientation may well prove instructive for judges who wish to eschew a more uniform or monolithic approach to resolving statutory disputes.

1525 (2003) (same); Davies, supra note 35, at 377-81 (arguing that Court acted strategically in ignoring clear Congressional preference in criminal law).

212 See Ledbetter, 550 U.S. at 627 n.2, 652-54 (dispute between majority and dissent on scope of Congress's 1991 override of Lorance v. AT\&T, 490 U.S. 900 (1989)); S. Rep. No. 101-263, at 29 (1990) (chastising Court decision in Betts for its restrictive interpretation of 1978 congressional override); Deborah A. Widiss, Shadow Precedents and the Separation of Powers: Statutory Interpretation of Congressional Overrides, 84 NOTRE DAME L. REV. 511 (2009).

213 On occasion, Justice Ginsburg confronts a statutory controversy that implicates both criminal law and civil rights-related considerations. In United States v. Hayes, 129 S. Ct. 1079 (2009), following a 1994 conviction for battery against his spouse, respondent was found in possession of a rifle and was indicted in 2005 for violation of a 1996 amendment to the federal Gun Control Act. Ginsburg's majority opinion took a progovernment view as to the scope of prohibited conduct in the context of a crime involving violence against women. The Court held that when Congress prohibited possession of firearms by persons convicted of "a misdemeanor crime of domestic violence," it did not make a domestic relationship a defining element of the predicate offense. See id. at 1084-89. 
